OPEN ACCESS

Edited by:

Shokrollah Elahi,

University of Alberta, Canada

Reviewed by:

Michaela Muller-Trutwin,

Institut Pasteur, France

Kehmia Titanji,

Emory University, United States

*Correspondence:

Persephone Borrow

persephone.borrow@ndm.ox.ac.uk

Specialty section:

This article was submitted to

Viral Immunology,

a section of the journal

Frontiers in Immunology

Received: 20 August 2020

Accepted: 27 October 2020

Published: 24 November 2020

Citation:

Dickinson M, Kliszczak $A E$

Giannoulatou E, Peppa D,

Pellegrino $P$, Williams I, Drakesmith $H$ and Borrow P (2020) Dynamics of

Transforming Growth Factor

(TGF)- $\beta$ Superfamily Cytokine Induction During HIV-1 Infection Are Distinct From Other Innate Cytokines.

Front. Immunol. 11:596841. doi: 10.3389/fimmu.2020.596841

\section{Dynamics of Transforming Growth Factor (TGF)- $\beta$ Superfamily Cytokine Induction During HIV-1 Infection Are Distinct From Other Innate Cytokines}

\author{
Matthew Dickinson ${ }^{1,2}$, Anna E. Kliszczak ${ }^{1}$, Eleni Giannoulatou ${ }^{3,4}$, Dimitra Peppa ${ }^{1,5}$, \\ Pierre Pellegrino ${ }^{6}$, lan Williams ${ }^{6}$, Hal Drakesmith $^{2}$ and Persephone Borrow ${ }^{1 *}$ \\ ${ }^{1}$ Nuffield Department of Clinical Medicine, University of Oxford, Oxford, United Kingdom, ${ }^{2}$ MRC Human Immunology Unit, \\ MRC Weatherall Institute of Molecular Medicine, University of Oxford, Oxford, United Kingdom, ${ }^{3}$ Computational Genomics \\ Laboratory, Victor Chang Cardiac Research Institute, Sydney, NSW, Australia, ${ }^{4}$ St Vincent's Clinical School, University of New \\ South Wales, Sydney, NSW, Australia, ${ }^{5}$ Mortimer Market Centre, Department of HIV, CNWL NHS Trust, London, United Kingdom, \\ ${ }^{6}$ Centre for Sexual Health and HIV Research, University College London, London, United Kingdom
}

Human immunodeficiency virus type 1 (HIV-1) infection triggers rapid induction of multiple innate cytokines including type I interferons, which play important roles in viral control and disease pathogenesis. The transforming growth factor (TGF)- $\beta$ superfamily is a pleiotropic innate cytokine family, some members of which (activins and bone morphogenetic proteins (BMPs)) were recently demonstrated to exert antiviral activity against Zika and hepatitis B and $C$ viruses but are poorly studied in HIV-1 infection. Here, we show that TGF- $\beta_{1}$ is systemically induced with very rapid kinetics (as early as $1-4$ days after viremic spread begins) in acute HIV-1 infection, likely due to release from platelets, and remains upregulated throughout infection. Contrastingly, no substantial systemic upregulation of activins $A$ and $B$ or BMP-2 was observed during acute infection, although plasma activin levels trended to be elevated during chronic infection. HIV-1 triggered production of type I interferons but not TGF- $\beta$ superfamily cytokines from plasmacytoid dendritic cells (DCs) in vitro, putatively explaining their differing in vivo induction; whilst lipopolysaccharide (but not HIV-1) elicited activin A production from myeloid DCs. These findings underscore the need for better definition of the protective and pathogenic capacity of TGF- $\beta$ superfamily cytokines, to enable appropriate modulation for therapeutic purposes.

Keywords: HIV, TGF-beta, activin, interferon, cytokine, dendritic cell, innate response, bone morphogenetic protein

\section{INTRODUCTION}

Effective prophylactic strategies are urgently required to halt the continued spread of the human immunodeficiency type 1 (HIV-1) pandemic. Furthermore, although an increasing proportion of HIV-infected individuals are now accessing combination antiretroviral therapy (ART) (1), there is a need for improved therapeutic regimes, both to facilitate long-term control (or even achieve a functional cure) of established infection and to block the ongoing inflammation and immune activation that accompanies even well-controlled HIV-1 replication, which is associated with 
substantial long-term morbidity (2). The rational design of novel strategies to reduce HIV-1 transmission and ameliorate the consequences of established infection has been revolutionized by recent advances in understanding of the immune responses activated following HIV-1 infection and their roles in protection and/or pathogenesis (3), and there is an important need for further insight into HIV-immune system interactions at different stages of infection to advance this field.

Disseminated viral replication in acute HIV-1 infection induces a systemic cytokine storm, with elevations in circulating levels of multiple cytokines and chemokines including type I interferons (IFNs) occurring as viremia escalates (4-6). Although the high-magnitude analyte elevations triggered prior to peak viremia are not sustained as viral replication declines, low-level perturbations continue into chronic infection $(7,8)$, reflecting dysregulated inflammation and immune activation (9). Analyte levels also fail to normalize after initiation of antiretroviral therapy $(\mathrm{ART})(7,10)$ as chronic inflammation persists (11). Innate cytokines such as type I IFNs mediate both beneficial and detrimental effects during HIV-1 infection, inhibiting viral replication $(12,13)$ but contributing to immune activation and pathogenesis (14). The lack of pathogenesis of simian immunodeficiency virus (SIV) infections in their natural hosts is associated with rapid downregulation of IFN responses and systemic inflammation after acute infection $(15,16)$.

The transforming growth factor (TGF)- $\beta$ superfamily is a group of pleiotropic cytokines that includes the three isoforms of TGF- $\beta$ (TGF- $\left.\beta_{1-3}\right)$, three activins ( $\mathrm{A}, \mathrm{B}$ and $\mathrm{AB}$ ), bone morphogenetic proteins (BMPs) and others (17). Like IFNs, TGF- $\beta$ superfamily members have pleiotropic effects on the activation, proliferation and differentiation of multiple cell types, including immune cell subsets (18-20). Recent research has also revealed that BMPs and activins exhibit antiviral activity against diverse RNA and DNA viruses including hepatitis $B$ virus (HBV), hepatitis $\mathrm{C}$ virus (HCV) and Zika virus $(21,22)$ through induction of an IFN-like transcriptional signature, with BMPs both enhancing type I IFN-mediated antiviral activity and also inhibiting viral replication independently of IFN (22). Activin A has also been shown to prevent reactivation of human cytomegalovirus (HCMV) in dendritic cells (DCs) in vitro (23).

Prior studies in non-human primate infection models have shown that a marked increase in plasma TGF- $\beta_{1}$ levels is induced within $24 \mathrm{~h}$ of intravenous inoculation of African green monkeys with SIVagm (a non-pathogenic infection model), but that this rapidly resolves (24). By contrast, in the pathogenic rhesus macaque SIVmac infection model, the initial increase in circulating TGF- $\beta_{1}$ levels is more modest, and plasma TGF- $\beta_{1}$ levels remain elevated throughout acute and early infection (24). Likewise, although the kinetics of TGF- $\beta_{1}$ induction during the earliest stages of HIV-1 infection have not been characterized, plasma TGF- $\beta_{1}$ levels in HIV-infected individuals studied during subacute and chronic infection have been found to be higher than those in HIV-seronegative control subjects (25-27), and correlate positively with levels of $\mathrm{T}$ cell activation in early infection (25) and with greater $\mathrm{CD}^{+} \mathrm{T}$ cell loss and enhanced disease progression during chronic infection $(26,27)$, However, with the exception of TGF- $\beta_{1}$, the roles of which in HIV-1 infection are complex and as yet incompletely understood (28), the TGF- $\beta$ superfamily remains poorly studied in HIV1 infection.

To gain insight into the extent and kinetics of systemic induction of different TGF- $\beta$ superfamily cytokines during natural HIV-1 infection, this study sought to measure levels of TGF- $\beta_{1}$, activins A and B and BMP-2 in plasma samples from $\mathrm{HIV}$-infected individuals during the acute, subacute and chronic phases of HIV-1 infection. Systemic induction of TGF- $\beta$ superfamily members was found to differ markedly from that of many other innate cytokines (including IFN- $\alpha$ ), with a modest but extremely rapid increase in plasma TGF- $\beta_{1}$ concentrations occurring as viremia first began to increase in acute HIV-1 infection that was then sustained throughout acute infection and into chronicity, whilst plasma concentrations of BMP-2 and activins $\mathrm{A}$ and $\mathrm{B}$ were largely unperturbed. Whereas in vitro exposure of DC subsets to HIV-1 elicited high levels of IFN- $\alpha$ production from plasmacytoid ( $\mathrm{p}$ )DCs, it failed to trigger production of TGF- $\beta_{1}$, BMP-2 or activins $A$ and B from either pDCs or myeloid (m)DCs, suggesting the importance of differences in the principal cellular sources of production of TGF- $\beta$ superfamily and other innate cytokines in determining their differing in vivo induction patterns.

\section{MATERIALS AND METHODS}

\section{Human Samples}

Longitudinal plasma samples from US plasma donors who initially showed no evidence of HIV-1 infection but during a serial plasma donation timespan were retrospectively found to have undergone HIV-1 seroconversion (4) were obtained from Zeptometrix Corporation (USA). Samples had been collected by plasmapheresis (a process that separates plasma from all the cellular components present in blood, including platelets) into $4 \%$ sodium citrate and cryopreserved. Serial samples from each donor cryopreserved at time-points prior to systemic detection of viremia (as determined by Quest Diagnostics Incorporated (USA) with a Roche Amplicor HIV Ultra assay (lowest level of detection 100 viral copies $/ \mathrm{ml}$ )) and during the phase of exponentially increasing viremia in acute infection were selected for analysis.

Whole blood from individuals recruited following clinical presentation with HIV-1 infection at the Mortimer Market Sexual Health Clinic (London, UK) and sampled during subacute and/or chronic infection was drawn into EDTA collection tubes, and plasma was separated and cryopreserved. Blood samples were processed within $6 \mathrm{~h}$ of withdrawal by diluting in $0.9 \%$ saline, underlaid with Histopaque-1077 (Sigma-Aldrich, USA), mononuclear cells separated by removal of the buffy coat, and erythrocytes/platelets pelleted by centrifugation. Diluted plasma was aliquoted and frozen at $-80^{\circ} \mathrm{C}$ for later use. Demographically matched seronegative control subjects were also recruited at the Mortimer Market Sexual Health Clinic, and 
plasma separated from blood samples was similarly cryopreserved. The vast majority of individuals were men who have sex with men (MSM) and of Caucasian ethnicity.

PBMCs were isolated by Histopaque (Sigma-Aldrich, USA) density gradient centrifugation from leukocyte reduction system chamber samples from healthy platelet donors that were purchased from NHS Blood \& Transplant, UK. Assays involving analysis of $\mathrm{pDC}$ function were performed on fresh, not cryopreserved samples.

\section{Viruses}

HIV-1 NL4-3 was generated from an infectious molecular clone (IMC) originally obtained from Drs John Kappes and Christina Ochsenbauer (UAB, USA). $10^{7} 293$ T cells in $75 \mathrm{~cm}^{2}$ surface area flasks were transfected with HIV-1 DNA using Lipofectamine 2000 (Sigma-Aldrich, USA). $12 \mu \mathrm{g}$ HIV-1 DNA in $1 \mathrm{ml}$ OptiMEM media (Thermo Fisher Scientific, USA) was combined with $25 \mu$ lipofectamine 2000 also in $1 \mathrm{ml}$ Opti-MEM. After allowing Lipofectamine-DNA complexes to form for $30 \mathrm{~min}$ at room temperature, the mixture was added to $8 \mathrm{ml}$ of DMEM (Thermo Fisher Scientific, USA) that had been supplemented with 10\% FBS, $2 \mathrm{mM}$-glutamine, 1\% non-essential amino acids and $100 \mathrm{IU} / \mathrm{ml}$ penicillin plus $100 \mu \mathrm{g} / \mathrm{ml}$ streptomycin and added to the flask. Virus-containing supernatants were harvested after $72 \mathrm{~h}$. Reverse transcriptase activity was determined using a colorimetric reverse transcriptase kit (Roche Diagnostics, Switzerland). The PR8 influenza virus stock (which had been produced and titered in MDCK-SIAT1 cells $(29,30)$ ) was a kind gift from Alain Townsend, University of Oxford, UK.

\section{ELISA and Luminex ${ }^{\circledR}$ Assays}

Activin A was measured using a human/mouse/rat activin A Quantikine ${ }^{\circledR}$ ELISA kit (Bio-Techne, USA). Activin B was measured by ELISA (Cloud-Clone Corp, USA). BMP-2 was measured using a BMP-2 Quantikine ${ }^{\circledR}$ ELISA kit (Bio-Techne, USA). IL-18 was measured using a human total IL-18 Quantikine ${ }^{\circledR}$ ELISA kit (Bio-Techne, USA). IFN- $\alpha$ was measured using a VeriKine human interferon alpha ELISA kit (PBL Assay Science, USA). PF4 was measured using a human PF4 Quantikine ${ }^{\circledR}$ ELISA kit (Bio-Techne, USA). Total (active and latent) TGF- $\beta_{1}$ was measured in plasma using a TGF- $\beta_{1}$ Magnetic Luminex ${ }^{\circledR}$ Performance Assay kit (Bio-Techne, USA) and in cell culture supernatants using a TGF- $\beta_{1}$ Quantikine ${ }^{\circledR}$ ELISA kit (BioTechne, USA) that both include an acid activation step prior to the assays. The manufacturer reports no significant cross-reactivity with other TGF- $\beta$ isoforms interfering with the measurement of TGF- $\beta_{1}$ in these assays. Lipopolysaccharide (LPS) was measured with a Kinetic-QCL ${ }^{\mathrm{TM}}$ LAL assay (Lonza, Switzerland). All assays were run according to the manufacturer's instructions, in technical duplicate or triplicate. The coefficient of variation (CV\%) was measured for all replicates, and only readings with an intra-well CV\% of $<20 \%$ were accepted.

As plasma levels of certain cytokines have been shown to be affected by long term sample cryostorage and freeze-thawing (3133 ) or anticoagulants $(31,32,34)$, quality control experiments were initially performed to address whether freeze-thawing or anticoagulant choice impacted on levels of the analytes measured here. Neither freeze-thawing nor anticoagulant use (EDTA, lithium heparin or $4 \%$ sodium citrate) was found to have a significant effect on plasma concentrations of TGF- $\beta_{1}$, activins A and B or BMP-2 (Supplementary Figure 1).

\section{Dendritic Cell Isolation and Culture}

Primary $\mathrm{CD} 1 \mathrm{c}^{+} / \mathrm{CD} 141^{+} \mathrm{mDCs}$ were isolated from PBMCs by negative selection using a MACS $^{\circledR}$ myeloid dendritic cell isolation kit (Miltenyi Biotec, Germany). pDCs were isolated from PBMCs by negative selection using a MACS ${ }^{\circledR}$ plasmacytoid dendritic cell isolation kit II (Miltenyi Biotec, Germany). Cells were cultured in R10 medium consisting of RPMI-1640 medium (Life Technologies, USA) supplemented with 10\% FBS (SigmaAldrich, USA), $2 \mathrm{mM}$ L-glutamine (GlutaMAX, Life Technologies, USA) and 100 units/ml penicillin plus $100 \mu \mathrm{g} / \mathrm{ml}$ streptomycin (Life Technologies, USA).

\section{In Vitro Analysis of Cytokine Production by DC Subsets}

$0.3-1.5 \times 10^{5} \mathrm{pDCs}$ or $0.3-0.7 \times 10^{5} \mathrm{mDCs}$ were plated/well into duplicate wells in flat-bottomed 96-well plates (Corning Inc, USA) and cultured in a total volume of $200 \mu \mathrm{l} /$ well R10 in the presence or absence of HIV-1 NL4-3 (50 ng RT/ml), PR8 influenza virus (MOI 10, based on plaque-forming units (PFU)/ml), LPS (100 ng/ml) (Sigma-Aldrich, USA), R837 (5 $\mu \mathrm{g} / \mathrm{ml}$ ) (Invivogen, USA), R848 (10 $\mu \mathrm{g} / \mathrm{ml})$ (Invivogen) or ODN $2216(5 \mu \mathrm{M})$ (Invivogen). After incubation for $24 \mathrm{~h}$ at $37^{\circ} \mathrm{C}$ in $5 \%$ $\mathrm{CO}_{2}$ supernatants were harvested and cytokine concentrations were analyzed by ELISA or Luminex ${ }^{\circledR}$ assay. Values for duplicate test wells were averaged.

\section{Statistics}

To enable longitudinal analysis of alterations in systemic cytokine concentrations during acute HIV-1 infection in the US plasma donor cohort (Figures 1 and 2), data from the different donors was temporally aligned based on $\mathrm{T}_{0}$ (the timepoint when viremia first reached $100 \mathrm{RNA}$ copies/ml plasma that was estimated using linear mixed-effects (LME) modelling as previously described (4)). Interpolation curves were created from longitudinal plasma cytokine data using the $\mathrm{R}$ package fields as previously described (35). LME models were used to compare cytokine concentrations of binned pre-day -7 samples to those in post-day -7 bins using $\mathrm{R}$ packages nlme and lme 4 as previously described (35).

Statistical analysis of other data was performed using GraphPad Prism version 8 (GraphPad Software Inc, USA). For cross-sectional data involving more than 2 groups (Figures 3A and $\mathbf{4 A}$ ), groups were compared by Kruskal-Wallis test with Dunn's post-hoc test for multiple comparisons. For paired analysis of cross-sectional data (Figures $\mathbf{3 B}$ and $4 \mathbf{B}$ ), two groups were compared by two-tailed Wilcoxon signed-rank test. Correlations were analyzed using two-tailed Spearman's rank correlation coefficient (Figures 4C-D). In vitro experiments analyzing induction of TGF- $\beta$ superfamily cytokines by DC subsets (Figures 5 and 6) were analyzed using a one-way ANOVA with Dunnett's ("many-to-one") post-test, comparing all groups to the medium control. 


\section{RESULTS}

\section{Circulating Levels of TGF- $\beta_{1}$, But Not Those of BMP-2 Or Activins A and B, Are Elevated in Acute HIV-1 Infection}

To elucidate the systemic kinetics of TGF- $\beta$ superfamily cytokines during acute HIV-1 infection, serial samples were studied from regular plasma donors who had become infected with HIV-1 during the plasma donation time-course, which provided a unique opportunity to gain insight into the systemic changes in analyte levels during the very earliest stages of HIV-1 infection (4). No information was available about donor identity or demographics. Plasma HIV-1 RNA levels in these samples had already been analyzed (4). The time-points selected for study included baseline samples taken a maximum of 132 days before viremia reached detectable levels (100 copies/ml viral RNA, referred to as the "time origin" or $\mathrm{T}_{0}$ ), and subsequent serial samples, typically drawn at 2- to 5-day intervals for up to 41 days post $\mathrm{T}_{0}$.

TGF- $\beta_{1}$, activin A and B and BMP-2 levels were measured in serial plasma samples from each donor. Examples of viral load and cytokine data from three representative subjects are shown in Figure 1; IFN- $\alpha$ concentrations in the same samples, measured as part of a prior study (4) have also been plotted to allow comparison with an innate antiviral cytokine known to be systemically upregulated as viremia increases during acute HIV-1 infection. As anticipated, some inter-donor variability in baseline analyte levels and minor temporal fluctuation in intradonor analyte levels was observed; and a transient elevation in IFN- $\alpha$ was apparent in two of these subjects. Two of the three donors showed evidence of an increase in plasma TGF- $\beta_{1}$ levels during the HIV-1 expansion phase, but there was no convincing evidence of upregulation of activin $\mathrm{A}$, activin $\mathrm{B}$ or BMP-2 following HIV-1 acquisition. To enable robust quantitative interrogation of perturbations in analyte levels over time, cytokine concentration and viral load data from 10 to 15 donors (depending on the analyte) were pooled and plotted as smoothed curves using spline interpolation (Figure 2A). Data were grouped into bins relative to $\mathrm{T}_{0}$, and linear mixed-effects models were fitted on the data, which take into account the variability between samples (Figure 2B). As perturbations in systemic levels of some analytes have been observed as early as 7 days before $\mathrm{T}_{0}$ (36), the mean plasma concentration of each analyte at time-points prior to day -7 was used as a baseline to which the mean values of other bins were compared to enable determination of alterations in cytokine concentrations during acute HIV-1 infection. Plasma levels of TGF- $\beta_{1}$ were significantly elevated as early 1 to 4 days post- $\mathrm{T}_{0}$ and remained similarly upregulated throughout acute infection (Figure 2B). By contrast, concentrations of activins A and $B$ remained largely unchanged over the course of acute HIV-1 infection (Figure 2B). There was a mild elevation in systemic BMP-2 concentration in acute HIV-1 infection at 9 to 12 days post- $\mathrm{T}_{0}$ (Figure 2B). However, this particular timepoint included fewer donors than the baseline bin, which may have skewed the data.

\section{Systemic Elevation of TGF- $\beta_{1}$, But Not BMP-2 or Activins A and B, Is Observed in Subacute and Chronic HIV-1 Infection}

To address whether TGF- $\beta$ superfamily cytokines are perturbed at subsequent stages of HIV-1 infection, plasma samples were obtained from a distinct cohort of subjects recruited following clinical presentation with acute HIV-1 infection. The majority of patients in this cohort were Caucasian MSM infected with HIV-1 subtype B. Plasma samples were available from $n=21$ subjects at a time-point during subacute infection, which was defined as the timeframe up to 30 days following the onset of acute retroviral syndrome symptoms (FOSx) (sampling time-points ranged from 5 to 29 days FOSx, median 12 days). All subacute infection samples were obtained prior to commencement of ART. A subset of the patients in this cohort declined ART and plasma samples were available from $n=26$ individuals (including 8 of the 21 subjects from whom samples were also available during subacute infection) at a chronic infection time-point more than two years FOSx, prior to which they had not received ART (range, 7531,570 days, median 1,243 days). The time-points at which infected individuals were studied, together with plasma viral load and CD4 count data, are shown in Table 1. Plasma samples from $n=20$ demographically matched HIV-seronegative subjects were studied in parallel, to enable cross-sectional analysis of plasma cytokine levels in control subjects, during subacute HIV1 infection and during chronic untreated HIV-1 infection. Notably, the fact that 8 of the patients in the subacute infection group declined ART and were also sampled during chronic untreated infection enabled analysis of paired data from both time-points in this subset of individuals. Circulating levels of IFN- $\alpha$ in most samples were below the limit of assay detection (data not shown), consistent with prior studies, which have shown that IFN- $\alpha$ is only transiently elevated prior to the peak in viremia in acute infection (4) and is commonly below detectable levels in chronic infection $(37,38)$. To provide comparative data for an innate cytokine expected to be detectably elevated in the circulation of viremic individuals, we assayed plasma levels of IL-18, a cytokine that has previously been shown to be strongly upregulated during acute infection (4) and then to decline in concentration but nonetheless remain slightly elevated during subacute and chronic infection $(37,38)$. Cross-sectional comparison of cytokine levels in seronegative controls and subjects sampled during subacute or chronic infection is shown in Figure 3A. Paired data from $n=8$ donors included in both the subacute and chronic infection groups is shown in Figure 3B. Consistent with observations made in other cohorts $(37,39)$, circulating IL-18 levels in the subjects studied here were found to be significantly higher than those in the seronegative control group during both subacute and chronic infection (Figure 3A). Plasma TGF- $\beta_{1}$ levels were likewise found to be significantly higher in both subacute and chronic infection than those in seronegative controls (Figure 3A), and there was a statistically significant increase in circulating TGF- $\beta_{1}$ levels from subacute to chronic infection (Figure 3B). By contrast, plasma concentrations of activins $\mathrm{A}$ and $\mathrm{B}$ and BMP-2 did not differ significantly from those in the seronegative controls (Figure 3A), 
64012

IFN-a

TGF- $\beta_{1}$

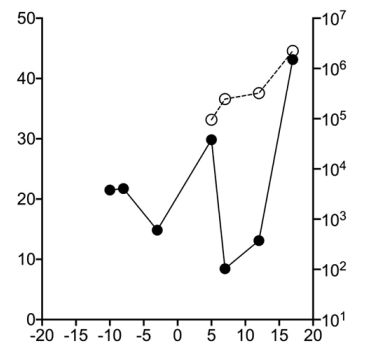

Activin A

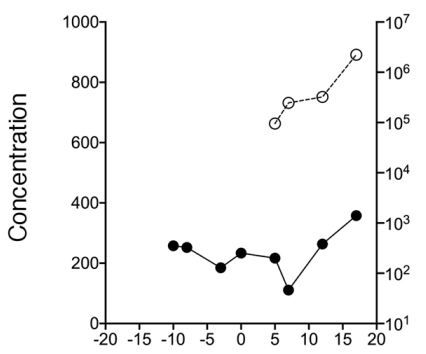

Activin B
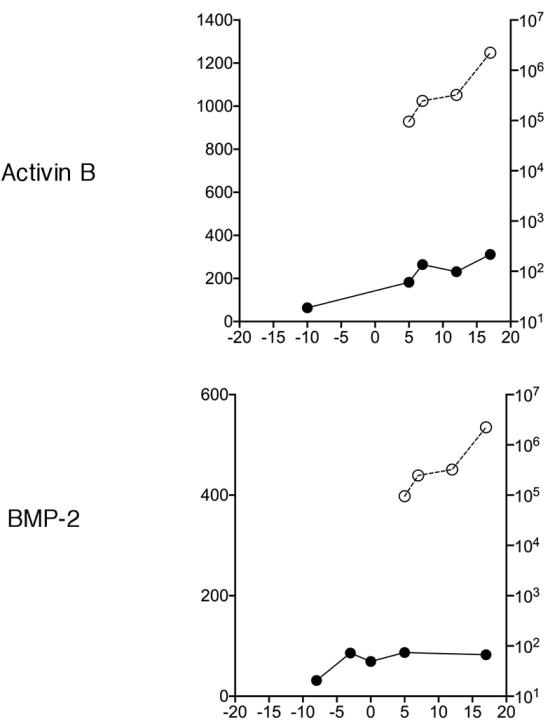

9015
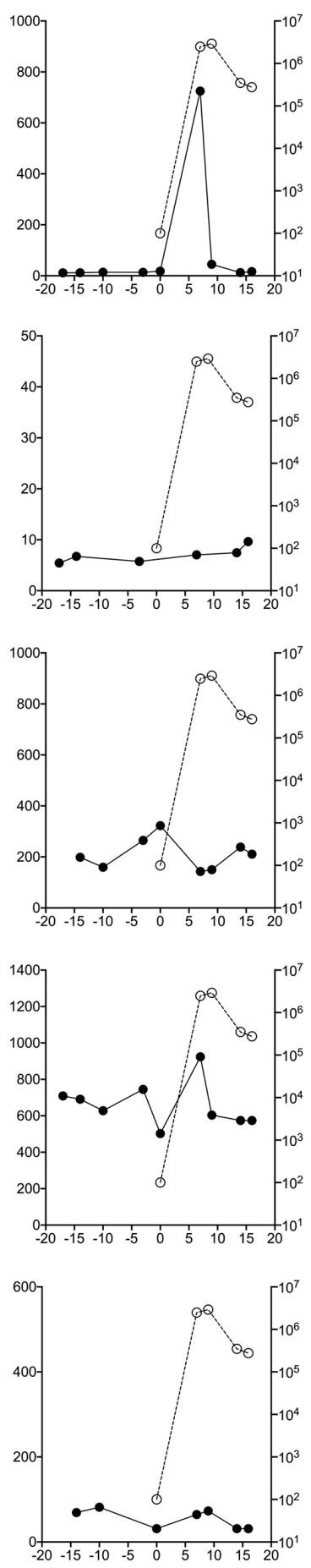

Time (days) relative to $T_{0}$
9010
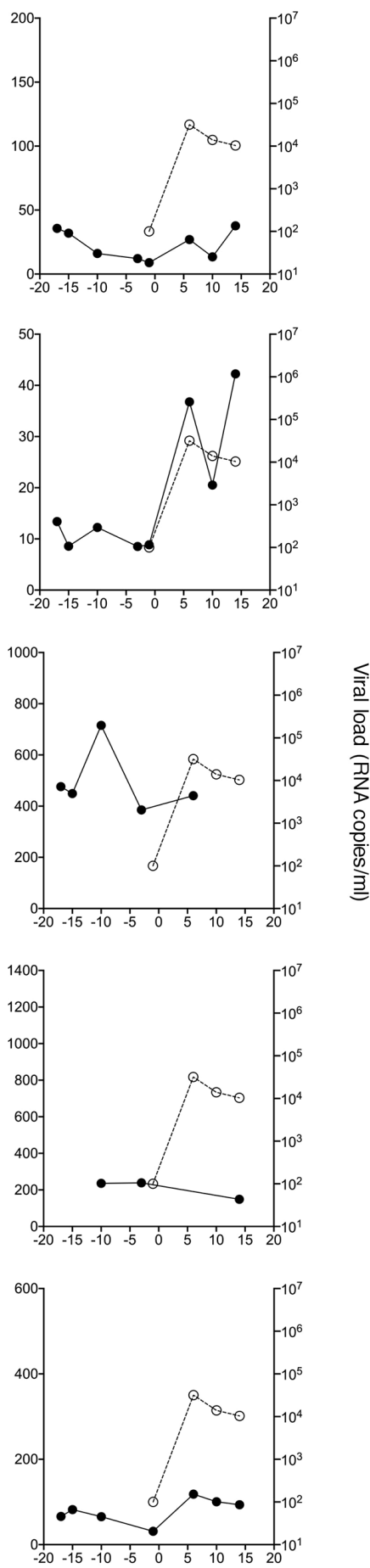

FIGURE 1 | Plasma concentrations of IFN- $\alpha$ and TGF- $\beta$ superfamily cytokines at serial time-points during acute HIV-1 infection in three donors. Circulating concentrations of TGF- $\beta_{1}$, activin A, activin B and BMP-2 were measured in serial plasma samples collected at time-points both pre- and post-To (the time-point when viral load first reached detectable levels (100 RNA copies/ml)) from plasma donors who became acutely infected with HIV-1. Data from three representative subjects is shown. Plasma IFN- $\alpha$ levels in the same individuals (evaluated as part of a prior study (4) are shown for comparison. Closed circles/solid lines represent cytokine concentrations (pg/ml, except TGF- $\beta_{1}$ which is in $\mathrm{ng} / \mathrm{ml}$ ); open circles/dashed lines represent plasma viral load (RNA copies/ml). 
A

IFN-a
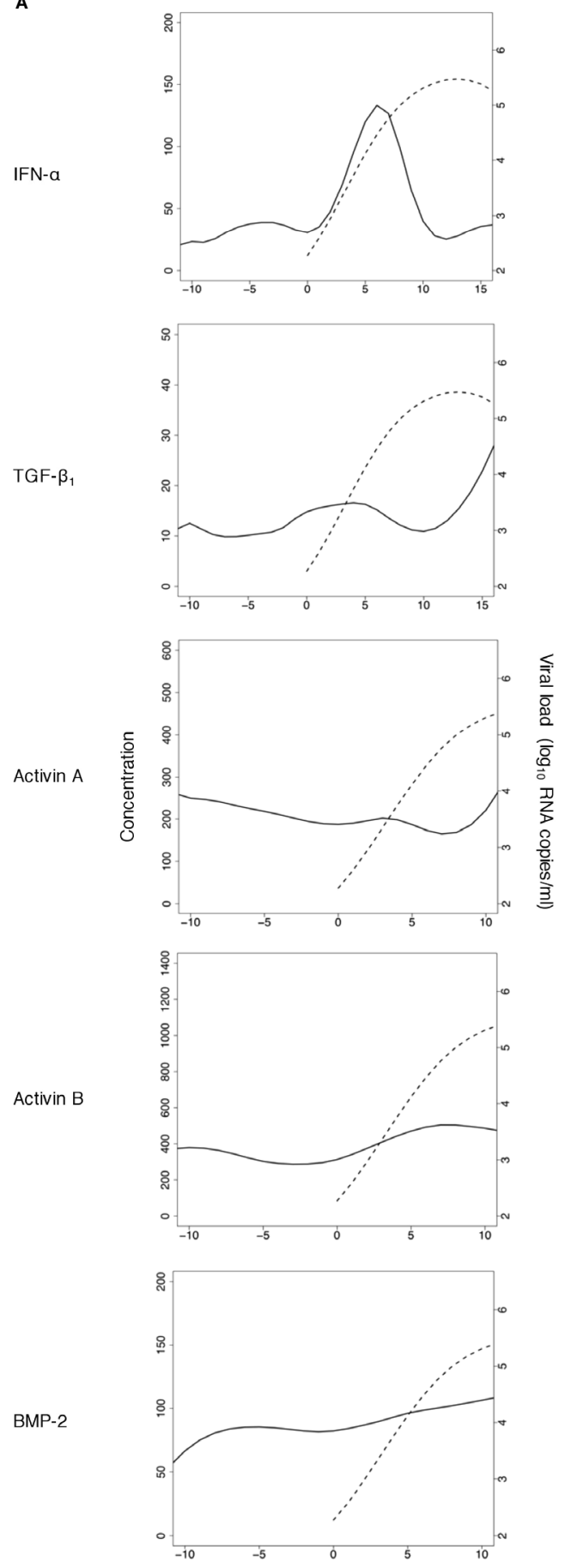

Time (days) relative to $T_{0}$
B

IFN-a

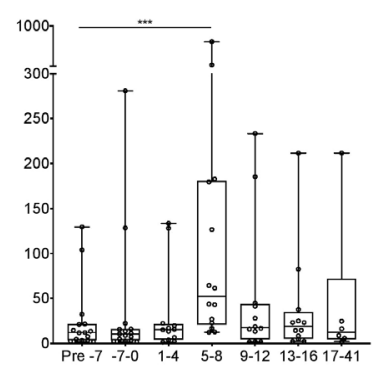

$\mathrm{TGF}-\beta_{1}$

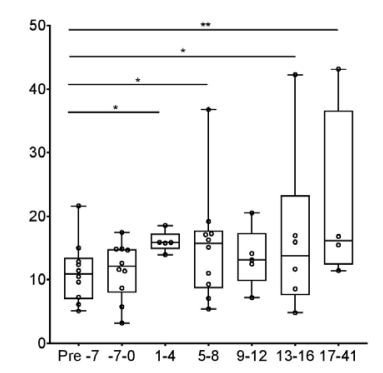

Activin A
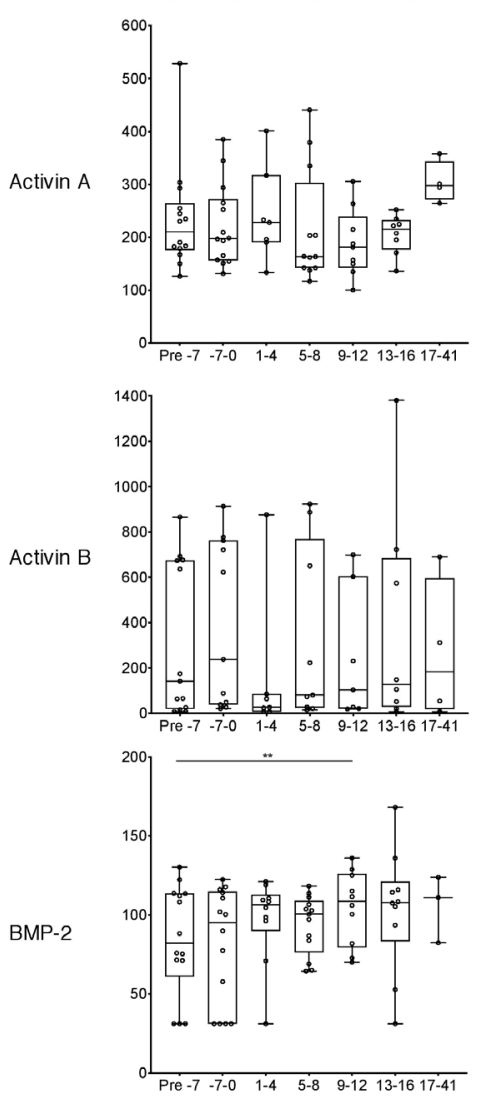

Time (days) relative to $T_{0}$

FIGURE 2 | Perturbations in plasma concentrations of IFN- $\alpha$ and TGF- $\beta$ superfamily cytokines during acute HIV- 1 infection. (A) TGF- $\beta_{1}$, activin A, activin B and BMP-2 concentrations were measured in plasma samples collected at time-points both pre- and post- $T_{0}$ (the time-point when viral load first reached detectable levels (100 RNA copies $/ \mathrm{ml})$ ) from plasma donors who became acutely infected with HIV-1 during the time-frame of serial plasma donation. IFN- $\alpha$ levels in the same samples had already been evaluated as part of a prior study (5). Data from $n=15$ (IFN- $\alpha$ ), $n=10$ (TGF- $\beta_{1}$ ), $n=14$ (activin A), $n=13$ (activin B), or $n=14$ (BMP-2) donor time-courses were combined and plotted using cubic interpolation splines. Solid lines represent cytokine concentrations (pg/ml, except TGF- $\beta_{1}$ which is in $\left.\mathrm{ng} / \mathrm{ml}\right)$, and dashed lines represent viral load (RNA copies $/ \mathrm{ml}$ ). (B) Pooled data were binned, and the pre- day -7 (relative to $\mathrm{T}_{0}$ ) bin was used as a baseline to which other bins were compared, using linear mixed-effects modelling $\left({ }^{\star} P<0.05,{ }^{* *} P<0.01,{ }^{* \star *} P<0.001\right)$. Box plots represent the limits of the 25 th and 75 th percentile, with the central line showing the median. Whiskers represent the range. All cytokine concentrations are in $\mathrm{pg} / \mathrm{ml}$, except TGF- $\beta_{1}$ which is in $\mathrm{ng} / \mathrm{ml}$. 

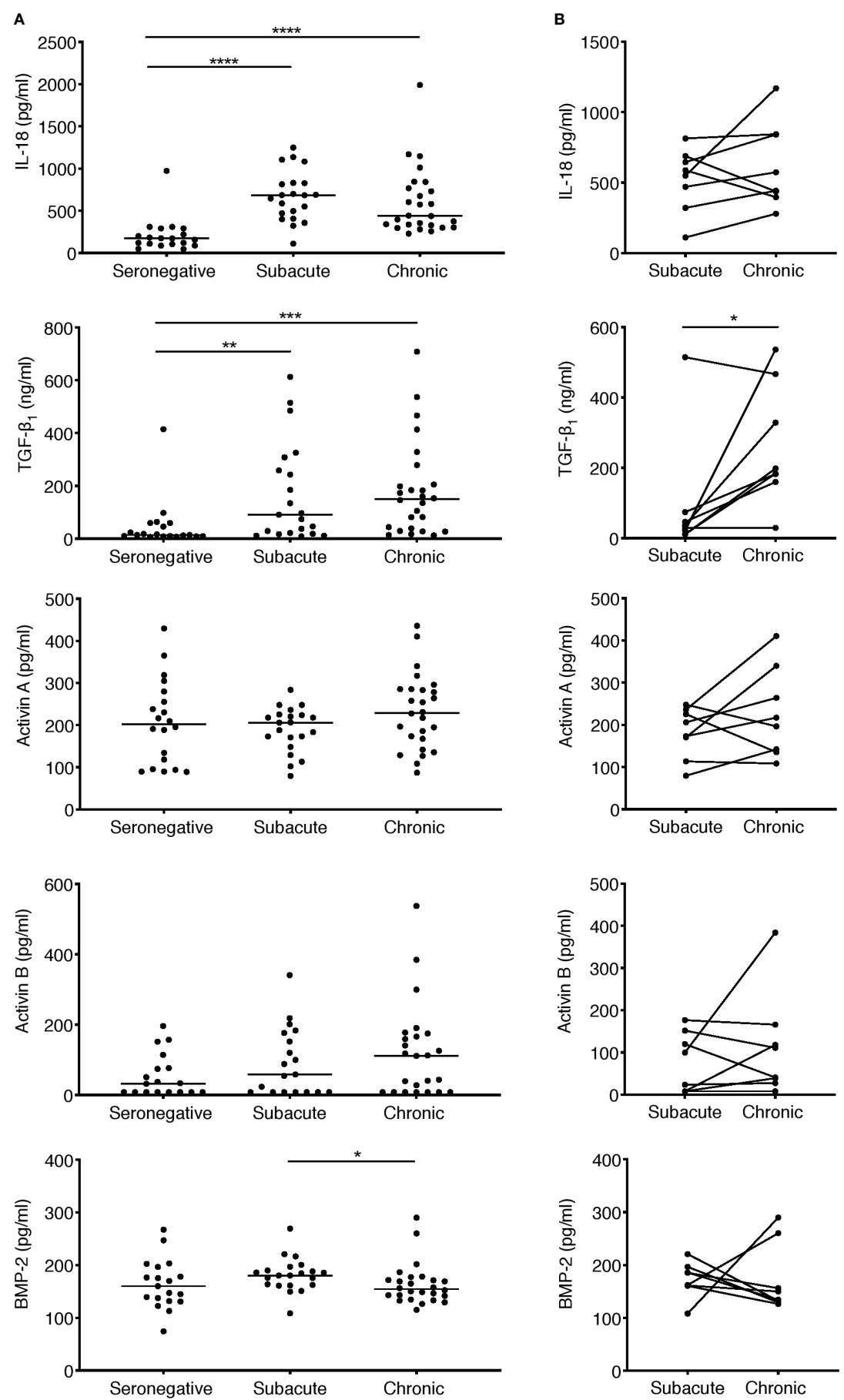

FIGURE 3 | Analysis of perturbations in plasma concentrations of IL-18 and TGF- $\beta$ superfamily cytokines in subacute and chronic HIV-1 infection.

(A) Concentrations of TGF- $\beta$ superfamily cytokines and IL-18 were measured in plasma samples from HIV-infected individuals sampled cross-sectionally during subacute (within 30 days FOSx) or chronic (> 2 years FOSx) untreated infection, and in demographically matched HIV-seronegative control subjects. Symbols represent datapoints from individual subjects ( $\mathrm{n}$ of datapoints included from seronegative, subacute and chronic groups: IL-18 and TGF- $\beta_{1} n=19,21,26$; activin A $n=20,21,26$; activin $B n=18,19,25$; BMP-2 n=19, 21, 26); and horizontal lines denote group medians. The statistical significance of differences between groups was determined by Kruskal-Wallis test with Dunn's post-test. (B) Samples were available from $n=8$ patients at time-points in both subacute and chronic untreated infection. Inter-time-point differences in cytokine levels in these subjects were compared by Wilcoxon signed-rank test $\left({ }^{\star} P<0.05,{ }^{\star \star} P<0.01,{ }^{\star \star \star} P<0.001\right.$, $\left.{ }^{* \star \star *} P<0.0001\right)$ 
A

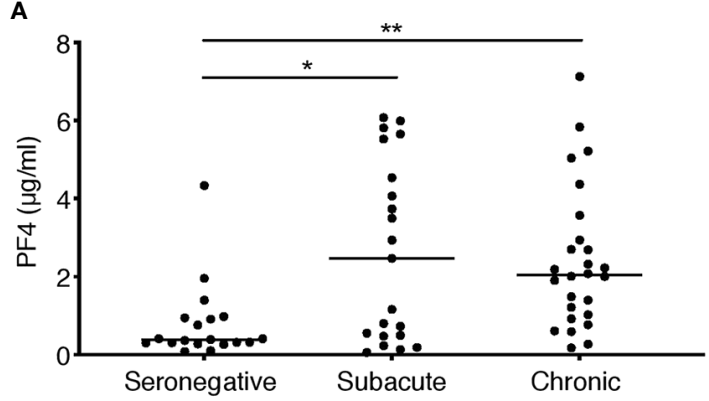

C

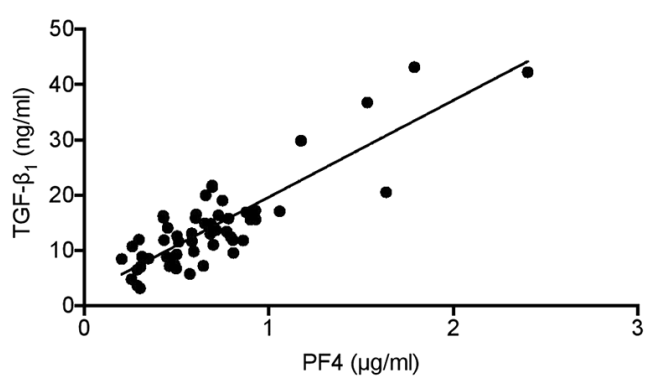

B

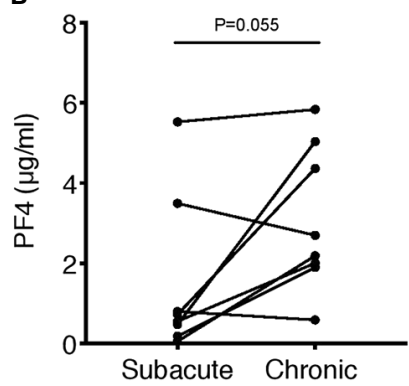

D

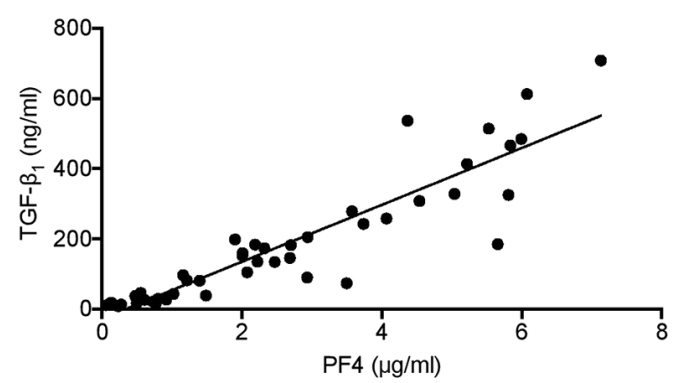

FIGURE 4 | Correlation between plasma concentrations of PF4 and TGF- $\beta_{1}$ in HIV-1-infected individuals. (A) PF4 levels were measured in plasma samples from the HIV-infected individuals sampled cross-sectionally during subacute (within 30 days FOSx) or chronic ( $>2$ years FOSx) untreated infection and demographically matched HIV-seronegative control subjects studied in Figure 3. Symbols represent datapoints from individual subjects (datapoints included: $\mathrm{n=19}$ seronegative, $n=21$ subacute and $n=26$ chronic); and horizontal lines denote the group median. The statistical significance of differences between groups was assessed by Kruskal-Wallis test with Dunn's post-test $\left.{ }^{\star} \mathrm{P}<0.05,{ }^{\star \star} \mathrm{P}<0.01\right)$. (B) Paired data from $\mathrm{n}=8$ subjects from whom samples were available at time-points in both subacute and chronic infection were analyzed by two-tailed Wilcoxon signed-rank test. (C) Correlation between TGF- $\beta_{1}$ and PF4 concentrations in $n=56$ samples from $n=9$ plasma donors acutely infected with HIV-1, analyzed by two-tailed Spearman's rank correlation coefficient $(r=0.71, P<0.0001)$. (D) Correlation between TGF- $\beta_{1}$ and PF4 concentrations in $n=47$ samples from $n=39$ individuals sampled during subacute and/or chronic HIV- 1 infection, analyzed by two-tailed Spearman's rank correlation coefficient $(r=0.94, P<0.0001)$.

although there was a trend for higher circulating levels of activins $\mathrm{A}$ and $\mathrm{B}$ in the chronic compared to the subacute infection group (Figure 3B). In order to assess whether microbial translocation could have driven this trend, LPS levels were measured in a subset of chronic donors from which enough plasma was remaining. No significant correlation was observed between the concentrations of LPS and activin A in these samples (data not shown).

\section{Elevated TGF- $\beta_{1}$ Correlates with Increased Platelet Degranulation in HIV-1 Infection}

Platelets are a major source of TGF- $\beta_{1}$ and release this cytokine upon activation and degranulation, along with alpha-granule chemokines such as CXCL4, also known as platelet factor 4 (PF4) (40). To assess platelet activation in subacute and chronic HIV-1 infection, cross-sectional samples from the subjects studied in Figure 3 were analyzed for PF4. Plasma PF4 was found to be significantly elevated in both subacute and chronic HIV-1 infection (Figure 4A) indicating marked platelet activation. In $\mathrm{n}=8$ donors from whom paired samples in subacute and chronic infection were available, there was no statistically significant increase in circulating PF4 concentration between these timepoints (Figure 4B).

PF4 was also measured in the samples from the acutely infected US plasma donor samples studied in Figure 2, where it was found to be positively correlated with TGF- $\beta_{1}$ concentration $(r=0.71, \mathrm{P}<0.0001)$ (Figure 4C). Similarly, when considering subacutely and chronically HIV-infected subjects together, PF4 positively correlated tightly $(r=0.94, \mathrm{P}<0.0001)$ with TGF- $\beta_{1}$ concentration (Figure 4D). Taken together, these data indicate that platelets are highly likely to be an important source of the TGF- $\beta_{1}$ present at elevated concentrations in plasma in acute, subacute and chronic HIV-1 infection.

\section{DCs Do Not Produce TGF- $\beta_{1}$, Activins A and B or BMP-2 Following In Vitro Exposure to HIV-1}

DCs are known to be rapidly activated during acute HIV-1 (and also SIV) infection (41-43). As DCs constitute an important cellular source of innate cytokines, and are known to be capable of producing (and responding to) a number of TGF- $\beta$ superfamily cytokines $(17,44)$, in vitro studies were conducted 

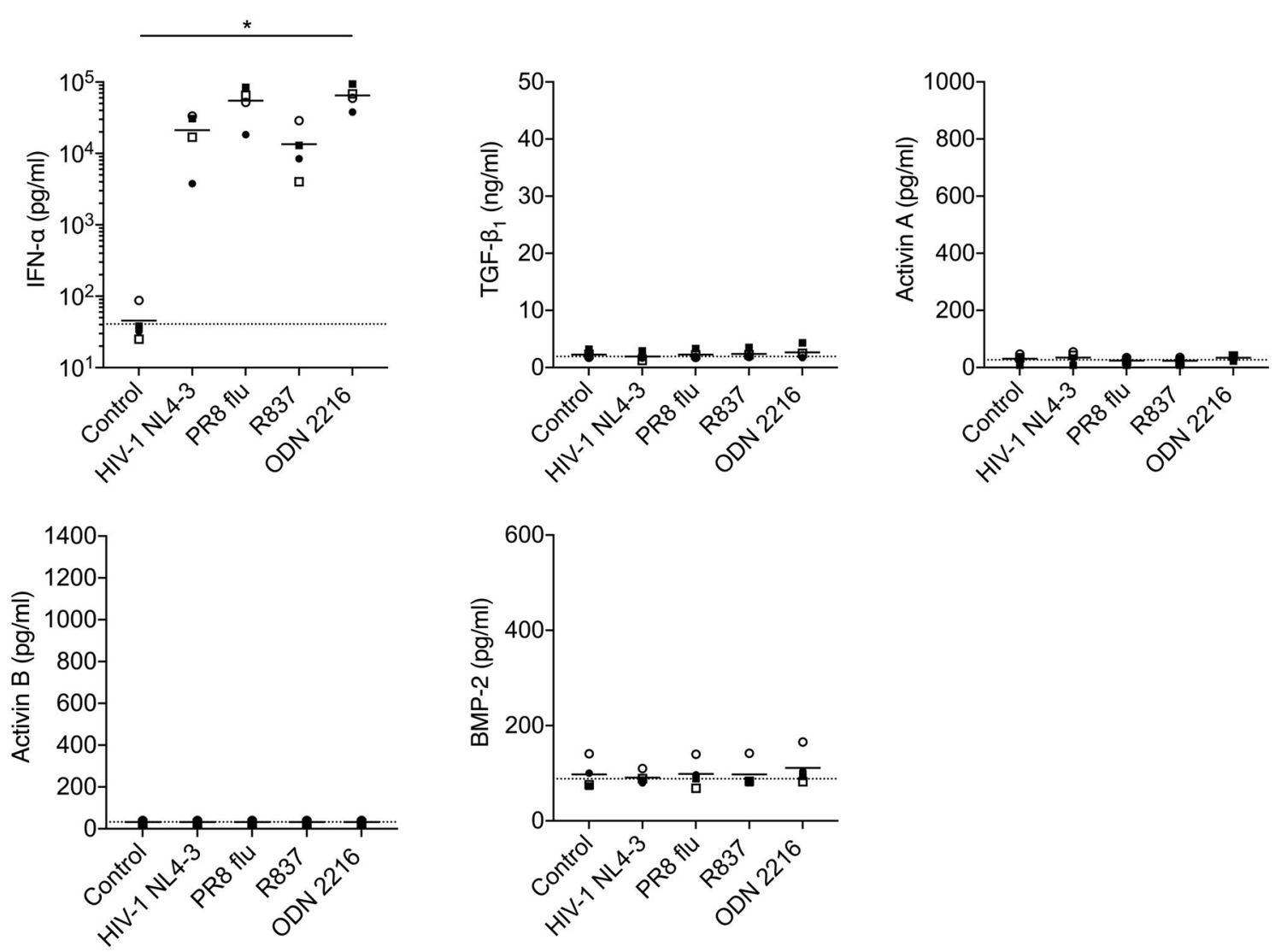

FIGURE 5 | Analysis of production of TGF- $\beta$ superfamily cytokines by pDCs following in vitro stimulation with HIV- 1 or TLR ligands. pDCs isolated from $n=4$ HIV-1seronegative donors were cultured with medium only, HIV-1 NL4-3, PR8 influenza virus, the TLR7 agonist R837, or the TLR9 agonist ODN 2216. Concentrations of IFN- $\alpha$ and TGF- $\beta$ superfamily cytokines in supernatants were measured after $24 \mathrm{~h}$. Symbols indicate datapoints from individual donors; horizontal solid lines represent group means. The horizontal dashed line shows background analyte levels in serum-containing medium (mean of values measured in two independent experiments). Data were analyzed using a one-way ANOVA with Dunnett's post-test comparing to the unstimulated pDC control ( $\left.{ }^{*} P<0.05\right)$.

to determine whether production of TGF- $\beta$ superfamily cytokines is triggered following exposure of primary pDCs or mDCs to HIV-1, TLR7/8 ligands [a surrogate for HIV-1 genomic RNA $(45,46)]$ and synthetic ligands for other TLRs expressed by these DC subsets. Although other leukocyte subsets, such as Treg cells, constitute an important source of TGF- $\beta_{1}$ in HIV and SIV infections (47), these cells are not directly activated by HIV-1 and are therefore unlikely to be the main source of the TGF- $\beta_{1}$ released into the circulation at the earliest timepoints after viremic HIV-1 spread begins to occur, so were not studied here.

Stimulation of pDCs with HIV-1, influenza virus (the genome of which also serves as a TLR7 ligand) or synthetic TLR7 (R837) or 9 (ODN2216) ligands elicited robust production of IFN- $\alpha$, but did not trigger release of TGF- $\beta_{1}$, activins $\mathrm{A}$ or B or BMP-2 (Figure 5). HIV-1 exposure also failed to elicit production of TGF- $\beta_{1}$, activins $\mathrm{A}$ or $\mathrm{B}$ or BMP-2 from $\mathrm{mDCs}$ (Figure 6), although mDCs did produce significant quantities of activin $\mathrm{A}$ in response to stimulation with the TLR4 ligand LPS [consistent with prior reports $(44,48)]$, and also released some activin A following exposure to a synthetic TLR7/8 ligand (R848).

\section{DISCUSSION}

This study addressed perturbations in systemic levels of diverse TGF- $\beta$ superfamily members (TGF- $\beta_{1}$, activins $A$ and $B$ and BMP-2) during the critical initial stages of HIV-1 infection and at time-points during subacute and chronic infection. Circulating concentrations of many other innate cytokines are transiently upregulated in a "storm" that begins $\sim 7$ days after first detection of viremia and continues until just after the peak virus replication, then normalize or exhibit less pronounced elevations during subacute and chronic infection. However, TGF- $\beta$ superfamily cytokines were found to behave distinctly. A moderate increase in plasma TGF- $\beta_{1}$ levels occurred as early as 1 to 4 days after first detection of viremia and persisted throughout the acute phase of infection, with elevations in circulating TGF- $\beta_{1}$ concentrations also being present during subacute and chronic infection. By contrast, no substantial perturbations were detected in systemic levels of the other TGF- $\beta$ superfamily members analyzed during acute or chronic infection, although there was a trend for an increase in 

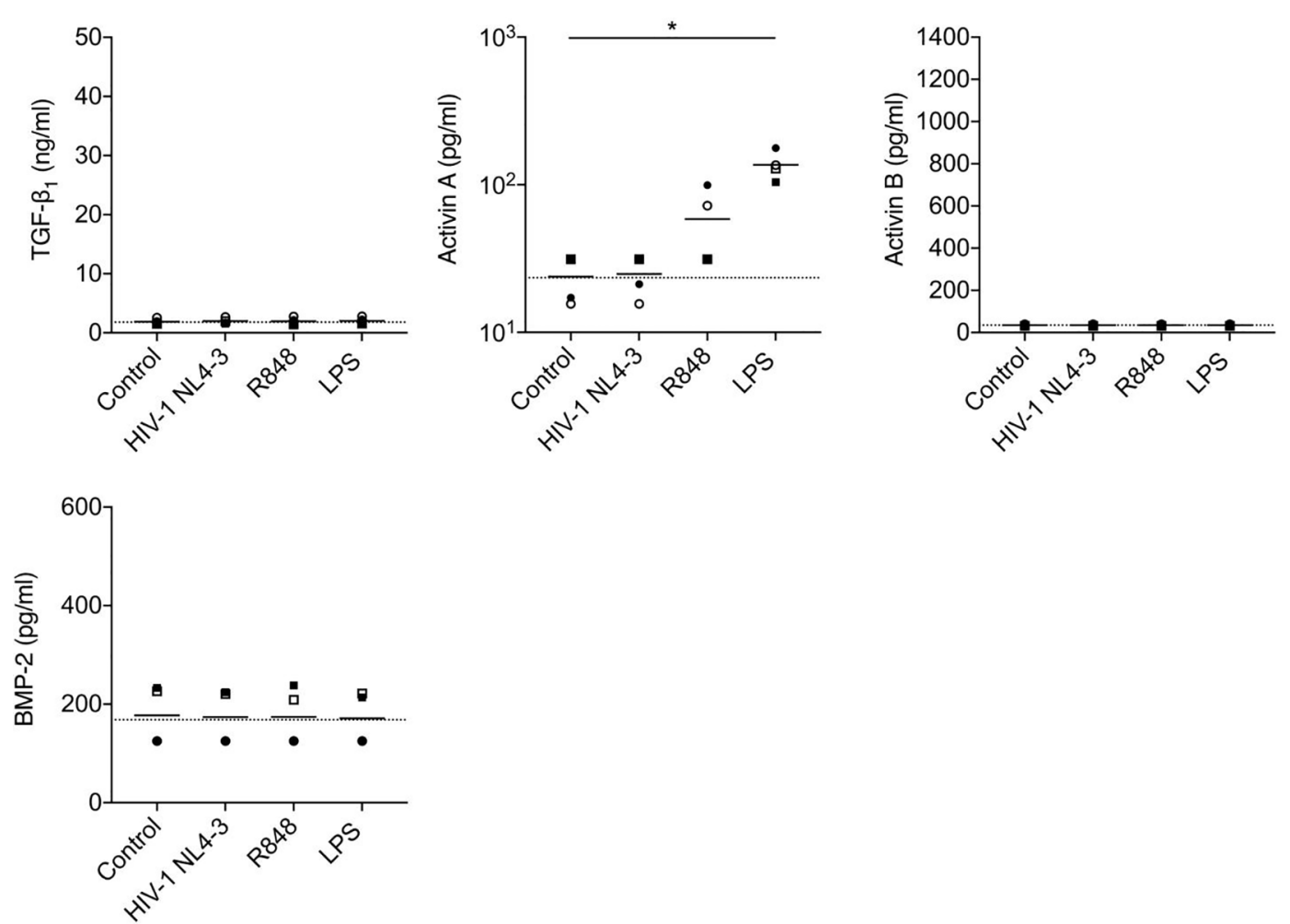

FIGURE 6 | Analysis of production of TGF- $\beta$ superfamily cytokines by mDCs following in vitro stimulation with HIV-1 or TLR ligands. mDCs from $n=4$ healthy donors were cultured with medium only, HIV-1 NL4-3, TLR7/8 agonist R848 or LPS. Concentrations of TGF- $\beta$ superfamily cytokines in supernatants were measured after $24 \mathrm{~h}$. The horizontal dashed line shows background analyte levels in serum-containing medium (mean of values measured in two independent experiments). Symbols represent data from four individual donors, solid lines indicate the group means. Data were analyzed using a one-way ANOVA with Dunnett's post-test comparing each group to the unstimulated $\mathrm{mDC}$ control ( $\left.{ }^{*} \mathrm{P}<0.05\right)$.

circulating activin $\mathrm{A}$ and $\mathrm{B}$ concentrations during chronic infection. Notably, in vitro analyses revealed that HIV-1 exposure of DC subsets, which comprise an important source of cytokine production during the acute phase of HIV-1 infection, did not elicit TGF- $\beta$ superfamily cytokine release, providing a putative explanation for the lack of a profound systemic upregulation of these cytokines during the innate cytokine "storm" in acute HIV-1 infection. However, the marked positive correlation between platelet activation and plasma TGF- $\beta_{1}$ levels in HIV-1 infection suggests that platelets may comprise an important source of sustained TGF- $\beta_{1}$ upregulation in HIV-infected individuals.

The kinetics of systemic elevation of TGF- $\beta_{1}$ during HIV-1 infection defined in this study parallel those reported in pathogenic non-human primate infection models such as SIVmac infection of rhesus macaques, where a modest increase in circulating TGF- $\beta_{1}$ levels is observed from as early as one day post-infection and is maintained throughout acute/subacute and into chronic infection (24), and increased transcription of genes downstream of TGF- $\beta$ signaling follows similar kinetics (49). Circulating TGF- $\beta_{1}$ levels in the earliest stages of acute HIV-1 infection have not previously been investigated, but our observation of elevations in plasma TGF- $\beta_{1}$ at later stages infection is consistent with findings from a number of other studies $(26,27,50-53)$. The modest and sustained systemic upregulation of TGF- $\beta_{1}$ in HIV-1 and pathogenic SIV infection contrasts sharply with the pattern of TGF- $\beta_{1}$ in nonpathogenic SIVagm infection of African green monkeys, where a robust $\mathrm{CD}^{+}$Treg cell response is activated one day after infection, with an associated pronounced increase in systemic TGF- $\beta_{1}$, but circulating TGF- $\beta_{1}$ concentrations during subacute and early chronic infection are in fact reduced compared those present prior to infection (24).

The differing kinetics of TGF- $\beta_{1}$ production in pathogenic and non-pathogenic immunodeficiency virus infections raise the hypothesis that like type I IFNs, TGF- $\beta_{1}$ may play both beneficial and detrimental roles during infection, with early induction contributing to protection whilst sustained upregulation has pathogenic consequences. In vitro studies suggest that TGF- $\beta_{1}$ may have complex, cell-type dependent effects on HIV-1 replication. In monocytes/macrophages it enhances HIV-1 replication (54-57). Conversely, in Langerhans cells TGF- $\beta_{1}$ restricts HIV-1 infection by inducing a post-entry block to virus replication (58). Moreover, by limiting immune activation very early after infection TGF- $\beta_{1}$ may putatively reduce the availability of activated $\mathrm{CD} 4^{+}$cells to support $\mathrm{HIV}-1$ 
TABLE 1 | Clinical data from donors subacutely and chronically infected with HIV-1.

\begin{tabular}{|c|c|c|c|c|c|c|c|c|c|}
\hline Group & $\begin{array}{l}\text { Subject } \\
\text { ID }\end{array}$ & $\begin{array}{l}\text { Days following } \\
\text { onset of symptoms }\end{array}$ & $\begin{array}{c}\text { Plasma viral load } \\
\text { (RNA copies/ml) }\end{array}$ & $\begin{array}{l}\text { CD4 count } \\
\text { (cells } / \mu \mathrm{l})\end{array}$ & Group & $\begin{array}{l}\text { Subject } \\
\text { ID }\end{array}$ & $\begin{array}{l}\text { Days following } \\
\text { onset of symptoms }\end{array}$ & $\begin{array}{c}\text { Plasma viral load } \\
\text { (RNA copies/ml) }\end{array}$ & $\begin{array}{l}\text { CD4 count } \\
\text { (cells/ } \mu \mathrm{l} \text { ) }\end{array}$ \\
\hline \multirow[t]{26}{*}{ Subacute } & MM12 & 16 & $1,555,700$ & 500 & Chronic & MM1 & 1370 & 29,700 & 1020 \\
\hline & MM19 & 13 & $5,678,900$ & 400 & & MM4 & 1222 & 233,400 & 490 \\
\hline & MM20 & 16 & $2,253,700$ & 220 & & MM8 & 801 & 105,200 & 240 \\
\hline & MM22 & 12 & $9,059,000$ & $N D^{\mathbf{b}}$ & & MM9 & 945 & 217,600 & 160 \\
\hline & $\mathrm{MM}^{2} 3^{\mathrm{a}}$ & 9 & $11,105,300$ & 330 & & MM12 & 900 & 304,800 & 200 \\
\hline & MM24 & 16 & 157,700 & 580 & & MM13 & 1125 & 8,800 & 240 \\
\hline & MM28 & 6 & $4,337,100$ & 560 & & MM14 & 1394 & 19,700 & 340 \\
\hline & МM31 & 20 & 324,000 & 370 & & MM23 & 1064 & 45,700 & 240 \\
\hline & MM32 & 10 & $147,640,000$ & 320 & & MM24 & 1322 & ND & 220 \\
\hline & ММз3 & 12 & $1,451,400$ & 940 & & MM27 & 1329 & 336,300 & 310 \\
\hline & ММ36 & 6 & $38,417,000$ & 320 & & MM28 & 1381 & 15,900 & 290 \\
\hline & MM38 & 29 & $2,721,100$ & 410 & & MM31 & 1220 & 153,000 & 750 \\
\hline & ММ39 & 5 & 350,600 & 610 & & ММз3 & 1441 & 30,000 & 440 \\
\hline & MM41 & 14 & $3,172,500$ & 190 & & MM34 & 1396 & 14,000 & 490 \\
\hline & MM65 & 10 & $5,000,000$ & 500 & & ММ36 & 1395 & 216,500 & $N D$ \\
\hline & MM67 & 24 & $8,300,000$ & 90 & & ММ39 & 1206 & 280,000 & 190 \\
\hline & MM69 & 12 & $5,100,000$ & 480 & & MM40 & 1530 & 310,000 & 250 \\
\hline & MM70 & 18 & $2,500,000$ & 260 & & MM45 & 1570 & 1,200 & 410 \\
\hline & MM72 & 5 & $2,100,000$ & 510 & & MM46 & 938 & 160,000 & 240 \\
\hline & MM73 & 11 & $3,700,000$ & 510 & & MM47 & 1263 & 24,000 & 210 \\
\hline & MM75 & 9 & $30,000,000$ & 320 & & MM51 & 906 & 27,000 & 560 \\
\hline & & & & & & MM55 & 1299 & 11,000 & 490 \\
\hline & & & & & & MM56 & 802 & 300 & 620 \\
\hline & & & & & & MM57 & 971 & 130,000 & 350 \\
\hline & & & & & & MM62 & 1173 & 20,000 & 1200 \\
\hline & & & & & & MM65 & 753 & 18,000 & 880 \\
\hline
\end{tabular}

${ }^{a}$ Donors sampled in both subacute and chronic infection are indicated in bold.

${ }^{b}$ Not determined.

replication and spread, although this has not been systematically investigated. During the initial stages of HIV-1 infection, when Langerhans cells may be infected and virus amplification in $\mathrm{CD} 4^{+}$ $\mathrm{T}$ cells is critical, TGF- $\beta_{1}$ may thus have a beneficial role overall. However, the sustained production of TGF- $\beta_{1}$ throughout the acute/subacute phases of SIVmac infection of rhesus macaques was found to be associated with upregulation of Smad7, an inhibitor of TGF- $\beta$ signaling, raising the hypothesis that early protective effects of TGF- $\beta_{1}$ may become blunted by subacute infection due to leukocytes becoming less responsive to this cytokine (59).

Although TGF- $\beta$ may play a role in limiting initial virus replication, given its ability to suppress the responses of multiple leukocyte subsets (60) it may indirectly enhance virus replication by limiting adaptive responses that play a key role in HIV-1 control, including both humoral and virus-specific $\mathrm{CD}^{+} \mathrm{T}$ cell responses, and this detrimental activity may start to predominate in early chronic infection. The importance of TGF- $\beta$ in regulation of $\mathrm{CD} 8^{+}$ $\mathrm{T}$ cell responses during chronic viral infection has been directly demonstrated in murine models (61); moreover, in SIV-infected macaques virus-specific $\mathrm{CD} 8^{+} \mathrm{T}$ cell frequencies correlate negatively with those of CD4 ${ }^{+}$Treg cells, a prominent source of TGF- $\beta$ (62). Chronic production of TGF- $\beta$ may also have other detrimental effects, e.g. TGF- $\beta$ mediates fibrosis of lymphoid tissue in HIV-1 infection (63). We did not observe any relationship between plasma TGF- $\beta_{1}$ levels during subacute or chronic HIV-1 infection and viral load or $\mathrm{CD}^{+} \mathrm{T}$ cell count in the relatively small cohort of individuals studied here, but in larger studies systemic TGF- $\beta_{1}$ has been found to be inversely correlated with $\operatorname{CD} 4$ count $(26,27)$, likewise circulating TGF- $\beta$ concentrations in individuals with nonprogressive HIV-1 infection are reported to be lower than in progressors (26). These observations are consistent with TGF- $\beta$ playing a pathogenic role during infection; although it cannot be excluded that TGF- $\beta$ upregulation is solely a marker of ongoing immune activation and associated disease progression rather than a determinant thereof. Pathogenic and non-pathogenic immunodeficiency virus infections are distinguished by sustained upregulation of IFN-stimulated gene (ISG) signatures in blood and lymphoid tissue cells in the former but not the latter $(15,16,64)$. Given the ability of TGF- $\beta$ superfamily members including activins and BMPs to promote ISG expression via both IFN-dependent and -independent mechanisms in certain cell types $(22,65)$, it could be speculated that sustained TGF- $\beta_{1}$ production during chronic infection may play a role in potentiating this pervasive, diseaseassociated ISG activation signature.

Notably, no substantial systemic elevation of activin A, activin B or BMP-2 was observed at any stage of HIV-1 infection, although there was a trend for higher circulating levels of activins A and B at later stages of infection. By contrast, multiple other innate cytokines are rapidly upregulated during acute HIV-1 infection and/or are more modestly elevated at later stages of infection $(4,5 \cdot 6,37,38)$. Notably, plasma activin A levels have been shown to increase in hepatitis $B$ and $C$ infections $(66,67)$, during septicemia $(68)$, and it contributes to inflammatory cascades and acute-phase protein upregulation (69). Given the intense immune activation and acute-phase 
protein production observed in HIV-1 infection, a highly inflammatory state $(4,6,36,70)$, the lack of pronounced activin A upregulation is striking.

DCs are key cellular sources of innate cytokine production in acute HIV-1 infection (41). Plasmacytoid DCs are directly activated by HIV-1, which binds to and is endocytosed by these cells, enabling TLR7-mediated sensing of the viral RNA genome (45). Proinflammatory cytokine release by pDCs then triggers cytokine production by myeloid DCs that are not directly activated by HIV-1 exposure (41). We showed that pDCs did not produce activin A or other TGF- $\beta$ superfamily cytokines following in vitro exposure to HIV or other activating stimuli that triggered potent type I IFN release from these cells; likewise, other studies similarly suggest that pDCs do not produce activin A $(44,71)$. This could explain the lack of systemic activin upregulation co-incident with type I IFN production as viremia first starts to increase in acute HIV-1 infection. However, mDCs are abundant producers of activin A. Unsurprisingly, HIV-1 exposure did not elicit activin release from mDCs, but activin A production was triggered by LPS, consistent with prior observations $(44,48)$. The trend for an increase in circulating activin A levels we observed in chronic HIV-1 infection may potentially be driven by LPS, which is known to translocate into circulation as a consequence of damage to gut-associated lymphoid tissues during the initial stages of infection (72). However, although HIV-1 does not directly stimulate $\mathrm{mDCs}, \mathrm{mDC}$ release of activin $\mathrm{A}$ can be triggered indirectly by tumor necrosis factor (TNF) (44); furthermore macrophages (73) and neutrophils (74) can also be stimulated to release activin $\mathrm{A}$ in the context of inflammation. This makes the lack of detectable systemic increase in activin A during the cytokine "storm" in acute infection when proinflammatory cytokines including TNF are known to be upregulated $(4,75)$ particularly remarkable.

TGF- $\beta$ is prominently produced by T cells, particularly Treg cells (76). However, these cells likely do not represent the source of the earliest elevations in TGF- $\beta_{1}$, as they are not directly stimulated by HIV-1 unless they have been pre-primed to respond to viral antigens. Accordingly, in one in vitro study where HIV- 1 antigens were shown to induce TGF- $\beta_{1}$ production from $\mathrm{CD}^{+}$and $\mathrm{CD}^{+}$Tregs from HIV-infected individuals within $24 \mathrm{~h}$ of stimulation, the source implicated was preestablished HIV-specific Tregs (77). In another study that stimulated PBMCs from HIV-seronegative donors with HIV-1 Env proteins and found production of TGF- $\beta_{1}$ within $48 \mathrm{~h}$, TGF$\beta_{1}$ induction was no longer observed when analyzing CD2enriched cells from the same donors (78). Thus, Tregs are less likely to constitute the main source of circulating TGF- $\beta_{1}$ in HIV-seronegative individuals in the earliest stages of infection. Nonetheless, Tregs likely do contribute to TGF- $\beta_{1}$ production at later times post-infection.

Platelets are an abundant cellular source of TGF- $\beta_{1}$ that is released upon activation and degranulation (79). The very rapid increase observed in plasma TGF- $\beta_{1}$ following the onset of viremia (which precedes activation of DCs and T cells), together with the strong correlation between TGF- $\beta_{1}$ and PF4 levels suggest that platelets are likely to be a dominant source of the TGF- $\beta_{1}$ found in the circulation during HIV-1 infection. Platelets can be artefactually activated after blood withdrawal due to the phlebotomy technique, physical agitation of samples, incorrect sample storage or improper platelet depletion during processing (80), and anticoagulants are also documented to cause some degree of platelet activation ex vivo $(81,82)$. PF4 is sometimes referred to as a marker of artefactual ex vivo platelet degranulation owing to its very short half-life in vivo (83). However, it is highly unlikely that the elevations in plasma TGF- $\beta_{1}$ observed in plasma samples from HIV-infected individuals are an artefact of ex vivo degranulation, as baseline and post-viremic plasma donor samples, and samples from HIV1-seronegative, subacute and chronically infected individuals were acquired and processed in a similar fashion, but time and group-dependent differences, respectively, were nonetheless observed. Furthermore, systemically elevated TGF- $\beta_{1}$ in HIVinfected individuals was also documented in a prior study where a robust platelet depletion protocol was employed (26). Together these observations support the hypothesis that parallel elevations in both TGF- $\beta_{1}$ and PF4 are elicited as a consequence of in vivo platelet activation during HIV-1 infection.

Notably, increased platelet activation in HIV-infected individuals has also been reported in other studies (84-88), and in SIV-infected macaques (89). The HIV-1 Tat protein activates platelets (90), and mice injected with Tat show a marked increase in plasma PF4 within $1 \mathrm{~h}(91,92)$, suggesting that Tat may be an important trigger of platelet activation to release TGF- $\beta_{1}$ prior to the activation of cellular innate responses as viremia begins during acute HIV-1 infection. Other mechanisms that may contribute to ongoing platelet activation in HIV-1 infection could include production of TNF, which activates platelets (93); and of platelet-activating factor (PAF), the bioactivity of which is increased in HIV-1 infection (94).

The demographics of the longitudinally-studied US plasma donors were unknown; but the cross-sectional plasma samples from subacute and/or chronically-infected UK donors were derived from Caucasian MSM. Important differences are observed in some aspects of the host immune response in individuals of differing sex or ethnicity. For example, pDCs of women produce more IFN- $\alpha$ than those of men when stimulated with HIV-1 (95), and in AHI, women generally establish a lower persisting viral load than men, but are then likely to progress to AIDS more rapidly than men with similar viral loads (96). It is thus important to consider how the demographics of the subjects studied here may have influenced the observations made. No difference has been observed in circulating levels of TGF- $\beta_{1}$ in male and female subjects in prior studies $(79,97,98)$, but differences have been reported in subjects of differing ethnicity, with higher circulating TGF- $\beta_{1}$ observed in black compared to white ethnic groups (99). However, although the chronicallyinfected subjects studied here were predominantly Caucasian, plasma TGF- $\beta_{1}$ levels in chronically HIV-1-infected subjects were also found to be higher than those in seronegative controls in another study where all participants were of black African 
ethnicity (51), and similar observations were also made in a study focusing on a relatively mixed group of Caucasian, Asian and black subjects (53). Thus, despite differences in baseline expression levels of TGF- $\beta_{1}$ between ethnic groups, the perturbations in systemic TGF- $\beta_{1}$ concentrations at different stages of HIV-1 infection observed in our study likely still occur in all infected individuals regardless of ethnicity.

In summary, we have demonstrated a very rapid systemic upregulation of TGF- $\beta_{1}$ in acute HIV-1 infection, likely due to platelet activation, which persists through subacute and chronic infection. By contrast, we show that other members of the TGF- $\beta$ superfamily are not substantially induced during acute/subacute infection, although low-level activin A/B may start to occur during chronic infection, putatively as a consequence of LPSdriven $\mathrm{mDC}$ stimulation of activin production. Further work is needed to define the effects of TGF- $\beta$ superfamily cytokines on HIV-1 replication, but as most members of this family are not produced at high levels during HIV-1 infection, if they do mediate antiviral activity against HIV-1 they could be exploited to restrict HIV-1 replication. Moreover, if sustained TGF- $\beta_{1}$ upregulation contributes to driving expression of inflammatory/IFN-ISG signatures in chronic infection, blocking the induction or activity of this cytokine could be considered to decrease excessive immune activation and associated pathology.

\section{DATA AVAILABILITY STATEMENT}

The raw data supporting the conclusions of this article will be made available by the authors on request, without undue reservation.

\section{ETHICS STATEMENT}

All human samples used in this study were obtained with appropriate ethical approval from relevant ethics committees (Local Research Ethics Committee for Camden and Islington and National Health Service Health Research Authority South Central Berkshire Research Ethics Committee for the samples from UK

\section{REFERENCES}

1. UNAIDS. UNAIDS data 2019 (2019). Available at: https://www.unaids.org/ sites/default/files/media_asset/2019-UNAIDS-data_en.pdf (Accessed 19 Aug 2020).

2. Deeks SG, Lewin SR, Havlir DV. The end of AIDS: HIV infection as a chronic disease. Lancet (2013) 382(9903):1525-33. doi: 10.1016/S0140-6736(13) 61809-7

3. Haynes BF, Shaw GM, Korber B, Kelsoe G, Sodroski J, Hahn BH, et al. HIVhost interactions: implications for vaccine design. Cell Host Microbe (2016) 19 (3):292-303. doi: 10.1016/j.chom.2016.02.002

4. Stacey AR, Norris PJ, Qin L, Haygreen EA, Taylor E, Heitman J, et al. Induction of a striking systemic cytokine cascade prior to peak viremia in acute human immunodeficiency virus type 1 infection, in contrast to more modest and delayed responses in acute hepatitis B and $\mathrm{C}$ virus infections. J Virol (2009) 83(8):3719-33. doi: 10.1128/JVI.01844-08
HIV-infected individuals and demographically-matched seronegative controls), and all study subjects provided written informed consent.

\section{AUTHOR CONTRIBUTIONS}

MD designed experiments, conducted experiments, acquired and assimilated data, and co-wrote the manuscript. AK produced HIV-1 NL4-3 from IMCs and quantified reverse transcriptase. EG performed statistical analysis of data. DP, PP, and IW provided clinical samples. HD advised on experimental design and provided feedback on the manuscript. $\mathrm{PB}$ conceived and directed the study, designed experiments, directed the assimilation of the data, provided reagents, and co-wrote the manuscript. All authors contributed to the article and approved the submitted version.

\section{FUNDING}

This work was supported by funding from the NIH, NIAID, DAIDS (R01 AI 114266) and the Medical Research Council $(\mathrm{MR} / \mathrm{K} 012037) . \mathrm{PB}$ is a Jenner Institute Investigator.

\section{ACKNOWLEDGMENTS}

The authors are extremely grateful to the donors who provided samples for this study and would also like to thank Drs John Kappes and Christina Ochsenbauer for supplying the HIV-1 NL4-3 IMC and Prof Alain Townsend for provision of a stock of influenza virus PR8.

\section{SUPPLEMENTARY MATERIAL}

The Supplementary Material for this article can be found online at: https://www.frontiersin.org/articles/10.3389/fimmu.2020. 596841/full\#supplementary-material

5. Roberts L, Passmore JA, Williamson C, Little F, Bebell LM, Mlisana K, et al Plasma cytokine levels during acute HIV-1 infection predict HIV disease progression. AIDS (2010) 24(6):819-31. doi: 10.1097/QAD.0b013e 3283367836

6. Muema DM, Akilimali NA, Ndumnego OC, Rasehlo SS, Durgiah R, Ojwach DBA, et al. Association between the cytokine storm, immune cell dynamics, and viral replicative capacity in hyperacute HIV infection. BMC Med (2020) 18(1):81. doi: 10.1186/s12916-020-01529-6

7. Keating SM, Golub ET, Nowicki M, Young M, Anastos K, Crystal H, et al. The effect of HIV infection and HAART on inflammatory biomarkers in a population-based cohort of women. AIDS (2011) 25(15):1823-32. doi: 10.1097/QAD.0b013e3283489d1f

8. Biancotto A, Grivel JC, Iglehart SJ, Vanpouille C, Lisco A, Sieg SF, et al. Abnormal activation and cytokine spectra in lymph nodes of people chronically infected with HIV-1. Blood (2007) 109(10):4272-9. doi: 10.1182/blood-2006-11-055764 
9. Brenchley JM, Price DA, Schacker TW, Asher TE, Silvestri G, Rao S, et al. Microbial translocation is a cause of systemic immune activation in chronic HIV infection. Nat Med (2006) 12(12):1365-71. doi: 10.1038/nm1511

10. Fernandez S, Tanaskovic S, Helbig K, Rajasuriar R, Kramski M, Murray JM, et al. CD4+ T-cell deficiency in HIV patients responding to antiretroviral therapy is associated with increased expression of interferon-stimulated genes in CD4+ T cells. J Infect Dis (2011) 204(12):1927-35. doi: 10.1093/infdis/ jir659

11. Klatt NR, Chomont N, Douek DC, Deeks SG. Immune activation and HIV persistence: implications for curative approaches to HIV infection. Immunol $\operatorname{Rev}(2013)$ 254(1):326-42. doi: 10.1111/imr.12065

12. Fenton-May AE, Dibben O, Emmerich T, Ding H, Pfafferott K, AasaChapman MM, et al. Relative resistance of HIV-1 founder viruses to control by interferon-alpha. Retrovirology (2013) 10:146. doi: 10.1186/17424690-10-146

13. Iyer SS, Bibollet-Ruche F, Sherrill-Mix S, Learn GH, Plenderleith L, Smith AG, et al. Resistance to type 1 interferons is a major determinant of HIV-1 transmission fitness. Proc Natl Acad Sci USA (2017) 114(4):E590-9. doi: 10.1073/pnas.1620144114

14. Le Saout C, Hasley RB, Imamichi H, Tcheung L, Hu Z, Luckey MA, et al. Chronic exposure to type-I IFN under lymphopenic conditions alters CD4 T cell homeostasis. PloS Pathog (2014) 10(3):e1003976. doi: 10.1371/ journal.ppat.1003976

15. Bosinger SE, Li Q, Gordon SN, Klatt NR, Duan L, Xu L, et al. Global genomic analysis reveals rapid control of a robust innate response in SIVinfected sooty mangabeys. J Clin Invest (2009) 119(12):3556-72. doi: $10.1172 / \mathrm{JCI} 40115$

16. Jacquelin B, Mayau V, Targat B, Liovat AS, Kunkel D, Petitjean G, et al. Nonpathogenic SIV infection of African green monkeys induces a strong but rapidly controlled type I IFN response. J Clin Invest (2009) 119(12):3544-55. doi: 10.1172/JCI40093

17. Seeger $P$, Musso T, Sozzani S. The TGF- $\beta$ superfamily in dendritic cell biology. Cytokine Growth Factor Rev (2015) 26(6):647-57. doi: 10.1016/ j.cytogfr.2015.06.002

18. Li MO, Flavell RA. TGF-beta: a master of all T cell trades. Cell (2008) 134 (3):392-404. doi: 10.1016/j.cell.2008.07.025

19. Morianos I, Papadopoulou G, Semitekolou M, Xanthou G. Activin-A in the regulation of immunity in health and disease. J Autoimmun (2019) 104:102314. doi: 10.1016/j.jaut.2019.102314

20. Martínez VG, Sacedón R, Hidalgo L, Valencia J, Fernández-Sevilla LM, Hernández-López $\mathrm{C}$, et al. The BMP pathway participates in human naive CD4+ T cell activation and homeostasis. PloS One (2015) 10(6):e0131453. doi: 10.1371/journal.pone.0131453

21. Eddowes LA, Al-Hourani K, Ramamurthy N, Frankish J, Baddock HT, Sandor C, et al. Antiviral activity of bone morphogenetic proteins and activins. Nat Microbiol (2019) 4(2):339-51. doi: 10.1038/s41564-018-0301-9

22. Sakamoto N, Yoshimura M, Kimura T, Toyama K, Sekine-Osajima Y, Watanabe $\mathrm{M}$, et al. Bone morphogenetic protein-7 and interferon-alpha synergistically suppress hepatitis C virus replicon. Biochem Biophys Res Commun (2007) 357(2):467-73. doi: 10.1016/j.bbrc.2007.03.167

23. Reeves MB, Compton T. Inhibition of inflammatory interleukin- 6 activity via extracellular signal-regulated kinase-mitogen-activated protein kinase signaling antagonizes human cytomegalovirus reactivation from dendritic cells. J Virol (2011) 85(23):12750-8. doi: 10.1128/JVI.05878-11

24. Kornfeld C, Ploquin MJ, Pandrea I, Faye A, Onanga R, Apetrei C, et al. Antiinflammatory profiles during primary SIV infection in African green monkeys are associated with protection against AIDS. J Clin Invest (2005) 115 (4):1082-91. doi: 10.1172/JCI23006

25. Liovat AS, Rey-Cuillé MA, Lécuroux C, Jacquelin B, Girault I, Petitjean G, et al. Acute plasma biomarkers of $\mathrm{T}$ cell activation set-point levels and of disease progression in HIV-1 infection. PloS One (2012) 7(10):e46143. doi: 10.1371 /journal.pone. 0046143

26. Wiercińska-Drapalo A, Flisiak R, Jaroszewicz J, Prokopowicz D. Increased plasma transforming growth factor-betal is associated with disease progression in HIV-1-infected patients. Viral Immunol (2004) 17(1):10913. doi: $10.1089 / 088282404322875502$

27. Maina EK, Abana CZ, Bukusi EA, Sedegah M, Lartey M, Ampofo WK. Plasma concentrations of transforming growth factor beta 1 in non-progressive HIV-
1 infection correlates with markers of disease progression. Cytokine (2016) 81:109-16. doi: 10.1016/j.cyto.2016.02.009

28. Theron AJ, Anderson R, Rossouw TM, Steel HC. The role of transforming growth factor beta-1 in the progression of HIV/AIDS and development of non-AIDS-defining fibrotic disorders. Front Immunol (2017) 8:1461. doi: 10.3389/fimmu.2017.01461

29. Matrosovich M, Matrosovich T, Carr J, Roberts NA, Klenk HD. Overexpression of the alpha-2,6-sialyltransferase in MDCK cells increases influenza virus sensitivity to neuraminidase inhibitors. J Virol (2003) 77 (15):8418-25. doi: 10.1128/jvi.77.15.8418-8425.2003

30. Matrosovich M, Matrosovich T, Garten W, Klenk HD. New low-viscosity overlay medium for viral plaque assays. Virol $J$ (2006) 3:63. doi: 10.1186/1743422X-3-63

31. de Jager W, Bourcier K, Rijkers GT, Prakken BJ, Seyfert-Margolis V. Prerequisites for cytokine measurements in clinical trials with multiplex immunoassays. BMC Immunol (2009) 10:52. doi: 10.1186/1471-2172-10-52

32. Flower L, Ahuja RH, Humphries SE, Mohamed-Ali V. Effects of sample handling on the stability of interleukin 6 , tumour necrosis factor-alpha and leptin. Cytokine (2000) 12(11):1712-6. doi: 10.1006/cyto.2000.0764

33. Aziz N, Nishanian P, Mitsuyasu R, Detels R, Fahey JL. Variables that affect assays for plasma cytokines and soluble activation markers. Clin Diagn Lab Immunol (1999) 6(1):89-95. doi: 10.1128/CDLI.6.1.89-95.1999

34. Biancotto A, Feng X, Langweiler M, Young NS, McCoy JP. Effect of anticoagulants on multiplexed measurement of cytokine/chemokines in healthy subjects. Cytokine (2012) 60(2):438-46. doi: 10.1016/ j.cyto.2012.05.019

35. Armitage AE, Stacey AR, Giannoulatou E, Marshall E, Sturges P, Chatha K, et al. Distinct patterns of hepcidin and iron regulation during HIV-1, HBV, and HCV infections. Proc Natl Acad Sci USA (2014) 111(33):12187-92. doi: 10.1073/pnas.1402351111

36. Kramer HB, Lavender KJ, Qin L, Stacey AR, Liu MK, di Gleria K, et al. Elevation of intact and proteolytic fragments of acute phase proteins constitutes the earliest systemic antiviral response in HIV-1 infection. PloS Pathog (2010) 6(5):e1000893. doi: 10.1371/journal.ppat.1000893

37. Gay C, Dibben O, Anderson JA, Stacey A, Mayo AJ, Norris PJ, et al. Crosssectional detection of acute HIV infection: timing of transmission, inflammation and antiretroviral therapy. PloS One (2011) 6(5):e19617. doi: 10.1371/journal.pone.0019617

38. von Sydow M, Sönnerborg A, Gaines H, Strannegård O. Interferon-alpha and tumor necrosis factor-alpha in serum of patients in various stages of HIV-1 infection. AIDS Res Hum Retroviruses (1991) 7(4):375-80. doi: 10.1089/ aid.1991.7.375

39. Ahmad R, Sindhu ST, Toma E, Morisset R, Ahmad A. Elevated levels of circulating interleukin-18 in human immunodeficiency virus-infected individuals: role of peripheral blood mononuclear cells and implications for AIDS pathogenesis. J Virol (2002) 76(24):12448-56. doi: 10.1128/ jvi.76.24.12448-12456.2002

40. Blair P, Flaumenhaft R. Platelet alpha-granules: basic biology and clinical correlates. Blood Rev (2009) 23(4):177-89. doi: 10.1016/j.blre. 2009.04.001

41. Sabado RL, O'Brien M, Subedi A, Qin L, Hu N, Taylor E, et al. Evidence of dysregulation of dendritic cells in primary HIV infection. Blood (2010) 116 (19):3839-52. doi: 10.1182/blood-2010-03-273763

42. Barratt-Boyes SM, Wijewardana V, Brown KN. In acute pathogenic SIV infection plasmacytoid dendritic cells are depleted from blood and lymph nodes despite mobilization. J Med Primatol (2010) 39(4):235-42. doi: 10.1111/ j.1600-0684.2010.00428.x

43. Wijewardana V, Kristoff J, Xu C, Ma D, Haret-Richter G, Stock JL, et al. Kinetics of myeloid dendritic cell trafficking and activation: impact on progressive, nonprogressive and controlled SIV infections. PloS Pathog (2013) 9(10):e1003600. doi: 10.1371/journal.ppat.1003600

44. Scutera S, Riboldi E, Daniele R, Elia AR, Fraone T, Castagnoli C, et al. Production and function of activin A in human dendritic cells. Eur Cytokine Netw (2008) 19(1):60-8. doi: 10.1684/ecn.2008.0121

45. Beignon AS, McKenna K, Skoberne M, Manches O, DaSilva I, Kavanagh DG, et al. Endocytosis of HIV-1 activates plasmacytoid dendritic cells via Toll-like receptor-viral RNA interactions. J Clin Invest (2005) 115(11):3265-75. doi: 10.1172/JCI26032 
46. Luban J. Innate immune sensing of HIV-1 by dendritic cells. Cell Host Microbe (2012) 12(4):408-18. doi: 10.1016/j.chom.2012.10.002

47. Chevalier MF, Weiss L. The split personality of regulatory T cells in HIV infection. Blood (2013) 121(1):29-37. doi: 10.1182/blood-2012-07-409755

48. Robson NC, Phillips DJ, McAlpine T, Shin A, Svobodova S, Toy T, et al. Activin-A: a novel dendritic cell-derived cytokine that potently attenuates CD40 ligand-specific cytokine and chemokine production. Blood (2008) 111 (5):2733-43. doi: 10.1182/blood-2007-03-080994

49. Barouch DH, Ghneim K, Bosche WJ, Li Y, Berkemeier B, Hull M, et al. Rapid inflammasome activation following mucosal SIV infection of Rhesus monkeys. Cell (2016) 165(3):656-67. doi: 10.1016/j.cell.2016.03.021

50. Márquez M, Romero-Cores $\mathrm{P}$, Montes-Oca M, Martín-Aspas A, SotoCárdenas MJ, Guerrero F, et al. Immune activation response in chronic HIV-infected patients: influence of Hepatitis C virus coinfection. PloS One (2015) 10(3):e0119568. doi: 10.1371/journal.pone.0119568

51. Malherbe G, Steel HC, Cassol S, de Oliveira T, Seebregts CJ, Anderson R, et al. Circulating biomarkers of immune activation distinguish viral suppression from nonsuppression in HAART-treated patients with advanced HIV-1 subtype C infection. Mediators Inflammation (2014) 2014:198413. doi: $10.1155 / 2014 / 198413$

52. Makhubele TG, Steel HC, Anderson R, van Dyk G, Theron AJ, Rossouw TM. Systemic immune activation profiles of HIV-1 subtype C-infected children and their mothers. Mediators Inflammation (2016) 2016:9026573. doi: $10.1155 / 2016 / 9026573$

53. Valdivia A, Ly J, Gonzalez L, Hussain P, Saing T, Islamoglu H, et al. Restoring cytokine balance in HIV-positive individuals with low CD4 T cell counts. AIDS Res Hum Retroviruses (2017) 33(9):905-18. doi: 10.1089/ AID.2016.0303

54. Lazdins JK, Klimkait T, Woods-Cook K, Walker M, Alteri E, Cox D, et al. In vitro effect of transforming growth factor-beta on progression of HIV-1 infection in primary mononuclear phagocytes. J Immunol (1991) 147 (4):1201-7.

55. Lima RG, Van Weyenbergh J, Saraiva EM, Barral-Netto M, Galvão-Castro B, Bou-Habib DC. The replication of human immunodeficiency virus type 1 in macrophages is enhanced after phagocytosis of apoptotic cells. J Infect Dis (2002) 185(11):1561-6. doi: 10.1086/340412

56. Chen S, Tuttle DL, Oshier JT, Knot HJ, Streit WJ, Goodenow MM, et al. Transforming growth factor-betal increases CXCR4 expression, stromalderived factor-1alpha-stimulated signalling and human immunodeficiency virus-1 entry in human monocyte-derived macrophages. Immunology (2005) 114(4):565-74. doi: 10.1111/j.1365-2567.2004.02110.x

57. Moriuchi M, Moriuchi H. Cell-type-dependent effect of transforming growth factor beta, a major cytokine in breast milk, on human immunodeficiency virus type 1 infection of mammary epithelial MCF-7 cells or macrophages. J Virol (2004) 78(23):13046-52. doi: 10.1128/JVI.78.23.13046-13052.2004

58. Czubala MA, Finsterbusch K, Ivory MO, Mitchell JP, Ahmed Z, Shimauchi T, et al. TGF $\beta$ induces a SAMHD1-independent post-entry restriction to HIV-1 infection of human epithelial Langerhans cells. J Invest Dermatol (2016) 136 (10):1981-9. doi: 10.1016/j.jid.2016.05.123

59. Ploquin MJ, Desoutter JF, Santos PR, Pandrea I, Diop OM, Hosmalin A, et al. Distinct expression profiles of TGF-betal signaling mediators in pathogenic SIVmac and non-pathogenic SIVagm infections. Retrovirology (2006) 3:37. doi: 10.1186/1742-4690-3-37

60. Batlle E, Massague J. Transforming growth factor- $\beta$ signaling in immunity and cancer. Immunity (2019) 50(4):924-40. doi: 10.1016/j.immuni.2019.03.024

61. Tinoco R, Alcalde V, Yang Y, Sauer K, Zuniga EI. Cell-intrinsic transforming growth factor-beta signaling mediates virus-specific CD8+ T cell deletion and viral persistence in vivo. Immunity (2009) 31(1):145-57. doi: 10.1016/ j.immuni.2009.06.015

62. Estes JD, Li Q, Reynolds MR, Wietgrefe S, Duan L, Schacker T, et al. Premature induction of an immunosuppressive regulatory $\mathrm{T}$ cell response during acute simian immunodeficiency virus infection. J Infect Dis (2006) 193 (5):703-12. doi: 10.1086/500368

63. Estes JD, Reilly C, Trubey CM, Fletcher CV, Cory TJ, Piatak M, et al. Antifibrotic therapy in simian immunodeficiency virus infection preserves CD4+ T-cell populations and improves immune reconstitution with antiretroviral therapy. J Infect Dis (2015) 211(5):744-54. doi: 10.1093/infdis/ jiu519
64. Lederer S, Favre D, Walters KA, Proll S, Kanwar B, Kasakow Z, et al. Transcriptional profiling in pathogenic and non-pathogenic SIV infections reveals significant distinctions in kinetics and tissue compartmentalization. PloS Pathog (2009) 5(2):e1000296. doi: 10.1371/journal.ppat.1000296

65. Olsavszky V, Ulbrich F, Singh S, Diett M, Sticht C, Schmid CD, et al. GATA4 and LMO3 balance angiocrine signaling and autocrine inflammatory activation by BMP2 in liver sinusoidal endothelial cells. Gene (2017) 627:491-9. doi: 10.1016/j.gene.2017.06.051

66. Refaat B, Ashshi AM, El-Shemi AG, AlZanbagi A. Effects of chronic hepatitis C genotype 1 and 4 on serum activins and follistatin in treatment naïve patients and their correlations with interleukin-6, tumour necrosis factor- $\alpha$, viral load and liver damage. Clin Exp Med (2015) 15(3):293-302. doi: 10.1007/ s10238-014-0297-2

67. Patella S, Phillips DJ, de Kretser DM, Evans LW, Groome NP, Sievert W. Characterization of serum activin-A and follistatin and their relation to virological and histological determinants in chronic viral hepatitis. $J$ Hepatol (2001) 34(4):576-83. doi: 10.1016/s0168-8278(00)00029-5

68. Michel U, Ebert S, Phillips D, Nau R. Serum concentrations of activin and follistatin are elevated and run in parallel in patients with septicemia. Eur $J$ Endocrinol (2003) 148(5):559-64. doi: 10.1530/eje.0.1480559

69. Jones KL, Mansell A, Patella S, Scott BJ, Hedger MP, de Kretser DM, et al. Activin A is a critical component of the inflammatory response, and its binding protein, follistatin, reduces mortality in endotoxemia. Proc Natl Acad Sci USA (2007) 104(41):16239-44. doi: 10.1073/pnas.0705971104

70. Paiardini M, Müller-Trutwin M. HIV-associated chronic immune activation. Immunol Rev (2013) 254(1):78-101. doi: 10.1111/imr.12079

71. Seeger P, Bosisio D, Parolini S, Badolato R, Gismondi A, Santoni A, et al. Activin $\mathrm{A}$ as a mediator of NK-dendritic cell functional interactions. J Immunol (2014) 192(3):1241-8. doi: 10.4049/jimmunol.1301487

72. Marchetti G, Tincati C, Silvestri G. Microbial translocation in the pathogenesis of HIV infection and AIDS. Clin Microbiol Rev (2013) 26 (1):2-18. doi: 10.1128/CMR.00050-12

73. Ebert S, Zeretzke M, Nau R, Michel U. Microglial cells and peritoneal macrophages release activin A upon stimulation with Toll-like receptor agonists. Neurosci Lett (2007) 413(3):241-4. doi: 10.1016/j.neulet. 2006.11.065

74. Chen Y, Wu H, Winnall WR, Loveland KL, Makanji Y, Phillips DJ, et al. Tumour necrosis factor- $\alpha$ stimulates human neutrophils to release preformed activin A. Immunol Cell Biol (2011) 89(8):889-96. doi: 10.1038/icb.2011.12

75. Vaidya SA, Korner C, Sirignano MN, Amero M, Bazner S, Rychert J, et al. Tumor necrosis factor $\alpha$ is associated with viral control and early disease progression in patients with HIV type 1 infection. J Infect Dis (2014) 210 (7):1042-6. doi: 10.1093/infdis/jiu206

76. Schmidt A, Oberle N, Krammer PH. Molecular mechanisms of Treg-mediated $\mathrm{T}$ cell suppression. Front Immunol (2012) 3:51. doi: 10.3389/fimmu. 2012.00051

77. Garba ML, Pilcher CD, Bingham AL, Eron J, Frelinger JA. HIV antigens can induce TGF-beta1-producing immunoregulatory CD8+ T cells. J Immunol (2002) 168(5):2247-54. doi: 10.4049/jimmunol.168.5.2247

78. Hu R, Oyaizu N, Than S, Kalyanaraman VS, Wang XP, Pahwa S. HIV-1 gp160 induces transforming growth factor-beta production in human PBMC. Clin Immunol Immunopathol (1996) 80(3 Pt 1):283-9. doi: 10.1006/clin.1996.0125

79. Grainger DJ, Mosedale DE, Metcalfe JC. TGF-beta in blood: a complex problem. Cytokine Growth Factor Rev (2000) 11(1-2):133-45. doi: 10.1016/ s1359-6101(99)00037-4

80. Coupes BM, Williams S, Roberts IS, Short CD, Brenchley PE. Plasma transforming growth factor beta(1) and platelet activation: implications for studies in transplant recipients. Nephrol Dial Transplant (2001) 16(2):361-7. doi: $10.1093 / \mathrm{ndt} / 16.2 .361$

81. Ahnadi CE, Sabrinah Chapman E, Lépine M, Okrongly D, Pujol-Moix N, Hernández $\mathrm{A}$, et al. Assessment of platelet activation in several different anticoagulants by the Advia 120 Hematology System, fluorescence flow cytometry, and electron microscopy. Thromb Haemost (2003) 90(5):940-8. doi: 10.1160/TH03-02-0097

82. Mussbacher M, Schrottmaier WC, Salzmann M, Brostjan C, Schmid JA, Starlinger P, et al. Optimized plasma preparation is essential to monitor platelet-stored molecules in humans. PloS One (2017) 12(12):e0188921. doi: 10.1371/journal.pone.0188921 
83. Dubrac A, Quemener C, Lacazette E, Lopez F, Zanibellato C, Wu WG, et al. Functional divergence between 2 chemokines is conferred by single amino acid change. Blood (2010) 116(22):4703-11. doi: 10.1182/blood-2010-03-274852

84. Mayne E, Funderburg NT, Sieg SF, Asaad R, Kalinowska M, Rodriguez B, et al. Increased platelet and microparticle activation in HIV infection: upregulation of P-selectin and tissue factor expression. J Acquir Immune Defic Syndr (2012) 59(4):340-6. doi: 10.1097/QAI.0b013e3182439355

85. Mesquita EC, Hottz ED, Amancio RT, Carneiro AB, Palhinha L, Coelho LE, et al. Persistent platelet activation and apoptosis in virologically suppressed HIVinfected individuals. Sci Rep (2018) 8(1):14999. doi: 10.1038/s41598-018-33403-0

86. Nkambule BB, Davison GM, Ipp H. The evaluation of platelet indices and markers of inflammation, coagulation and disease progression in treatmentnaïve, asymptomatic HIV-infected individuals. Int J Lab Hematol (2015) 37 (4):450-8. doi: 10.1111/ijlh.12307

87. Holme PA, Müller F, Solum NO, Brosstad F, Frøland SS, Aukrust P. Enhanced activation of platelets with abnormal release of RANTES in human immunodeficiency virus type 1 infection. FASEB J (1998) 12(1):79-89. doi: 10.1096/fasebj.12.1.79

88. O’Halloran JA, Dunne E, Gurwith M, Lambert JS, Sheehan GJ, Feeney ER, et al. The effect of initiation of antiretroviral therapy on monocyte, endothelial and platelet function in HIV-1 infection. HIV Med (2015) 16(10):608-19. doi: 10.1111/hiv.12270

89. Metcalf Pate KA, Lyons CE, Dorsey JL, Shirk EN, Queen SE, Adams RJ, et al. Platelet activation and platelet-monocyte aggregate formation contribute to decreased platelet count during acute simian immunodeficiency virus infection in pig-tailed macaques. J Infect Dis (2013) 208(6):874-83. doi: 10.1093/infdis/jit278

90. Wang J, Zhang W, Nardi MA, Li Z. HIV-1 Tat-induced platelet activation and release of CD154 contribute to HIV-1-associated autoimmune thrombocytopenia. J Thromb Haemost (2011) 9(3):562-73. doi: 10.1111/j.1538-7836.2010.04168.x

91. Davidson DC, Hirschman MP, Spinelli SL, Morrell CN, Schifitto G, Phipps $\mathrm{RP}$, et al. Antiplatelet activity of valproic acid contributes to decreased soluble CD40 ligand production in HIV type 1-infected individuals. J Immunol (2011) 186(1):584-91. doi: 10.4049/jimmunol.1001911

92. Davidson DC, Hirschman MP, Sun A, Singh MV, Kasischke K, Maggirwar SB. Excess soluble CD40L contributes to blood brain barrier permeability in vivo: implications for HIV-associated neurocognitive disorders. PloS One (2012) 7 (12):e51793. doi: 10.1371/journal.pone.0051793
93. Piguet PF, Vesin C, Da Kan C. Activation of platelet caspases by TNF and its consequences for kinetics. Cytokine (2002) 18(4):222-30. doi: 10.1006/ cyto.2002.0889

94. Tsoupras AB, Chini M, Mangafas N, Tsogas N, Stamatakis G, Tsantila N, et al. Platelet-activating factor and its basic metabolic enzymes in blood of naive HIV-infected patients. Angiology (2012) 63(5):343-52. doi: 10.1177/ 0003319711420608

95. Meier A, Chang JJ, Chan ES, Pollard RB, Sidhu HK, Kulkarni S, et al. Sex differences in the Toll-like receptor-mediated response of plasmacytoid dendritic cells to HIV-1. Nat Med (2009) 15(8):955-9. doi: 10.1038/ nm.2004

96. Farzadegan H, Hoover DR, Astemborski J, Lyles CM, Margolick JB, Markham $\mathrm{RB}$, et al. Sex differences in HIV-1 viral load and progression to AIDS. Lancet (1998) 352(9139):1510-4. doi: 10.1016/S0140-6736(98)02372-1

97. Frydecka D, Misiak B, Pawlak-Adamska E, Karabon L, Tomkiewicz A, Sedlaczek $P$, et al. Sex differences in TGFB- $\beta$ signaling with respect to age of onset and cognitive functioning in schizophrenia. Neuropsychiatr Dis Treat (2015) 11:575-84. doi: 10.2147/NDT.S74672

98. Young DG, Skibinski G, Mason JI, James K. The influence of age and gender on serum dehydroepiandrosterone sulphate (DHEA-S), IL-6, IL-6 soluble receptor (IL-6 sR) and transforming growth factor beta 1 (TGF-beta1) levels in normal healthy blood donors. Clin Exp Immunol (1999) 117(3):476-81. doi: 10.1046/j.1365-2249.1999.01003.x

99. August P, Sharma V, Ding R, Schwartz JE, Suthanthiran M. Transforming growth factor beta and excess burden of renal disease. Trans Am Clin Climatol Assoc (2009) 120:61-72.

Conflict of Interest: The authors declare that the research was conducted in the absence of any commercial or financial relationships that could be construed as a potential conflict of interest.

Copyright (c) 2020 Dickinson, Kliszczak, Giannoulatou, Peppa, Pellegrino, Williams, Drakesmith and Borrow. This is an open-access article distributed under the terms of the Creative Commons Attribution License (CC BY). The use, distribution or reproduction in other forums is permitted, provided the original author(s) and the copyright owner(s) are credited and that the original publication in this journal is cited, in accordance with accepted academic practice. No use, distribution or reproduction is permitted which does not comply with these terms. 